This item was submitted to Loughborough's Research Repository by the author.

Items in Figshare are protected by copyright, with all rights reserved, unless otherwise indicated.

\title{
Denazification and integration in the Austrian Province of Carinthia
}

PLEASE CITE THE PUBLISHED VERSION

PUBLISHER

(c) The University of Chicago Press

LICENCE

CC BY-NC-ND 4.0

REPOSITORY RECORD

Knight, Robert. 2019. "Denazification and Integration in the Austrian Province of Carinthia". figshare. https://hdl.handle.net/2134/3061. 
This item was submitted to Loughborough's Institutional Repository by the author and is made available under the following Creative Commons Licence conditions.

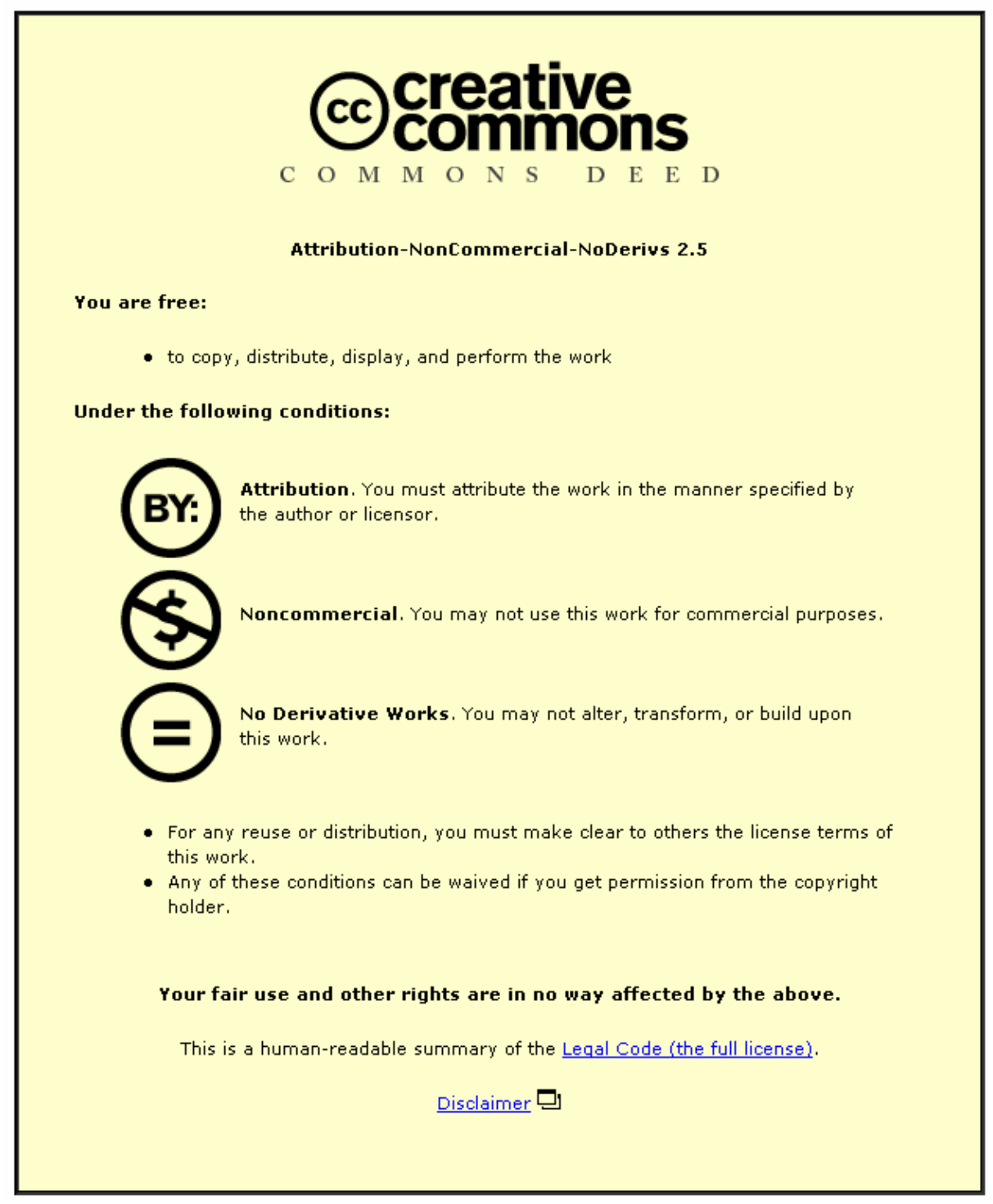

For the full text of this licence, please go to: http://creativecommons.org/licenses/by-nc-nd/2.5/ 


\title{
Denazification and Integration in the Austrian Province of Carinthia*
}

\author{
Robert Knight \\ Loughborough University
}

\section{INTRODUCTION}

Denazification - whether defined narrowly as a political purge or more broadly as an attempt to change the values of post-Nazi society - has not enjoyed a good press. ${ }^{1}$ In the case of Austria, as in the two German "successor societies" of the Third Reich, criticism has divided roughly into a conservative and a "left-liberal" position. The former has weighed denazification in the balance against Western legal principles (notably the prohibition of "retroactivity" and collective punishment) and found it wanting. ${ }^{2}$ Dieter Stiefel's 1981 study (still the only monograph on Austrian denazification) is clearly in this tradition, though its juridical concerns are overlaid by two further considerations, sovereignty and the rationality of integration. ${ }^{3}$ Taken together, these three factors make denazification appear to Stiefel not merely as a legally dubious project but also as an unwarranted and often inept Allied interference in Austrian society. It sought to deny the inevitable reintegration of the mass of Nazi Party members (in Austria amounting to nearly seven hundred thousand people) but could only delay it. ${ }^{4}$

\footnotetext{
* I would like to thank the British Academy (Elisabeth Barker Fund) for supporting the research for this article and the two anonymous $J M H$ reviewers for their constructive criticism. I wish to dedicate this article to the memory of Elisabeth Barker.

${ }^{1}$ For historiography, see the classic work by Lutz Niethammer, Entnazifizierung in Bayern: Säuberung und Rehabilitierung unter amerikanischer Besatzung (Frankfurt am Main, 1972), 11-24; and, more recently, Klaus-Dietmar Henke, "Die Trennung vom Nationalsozialismus: Selbstzerstörung, politische Säuberung, 'Entnazifizierung,' Strafverfolgung," in Politische Säuberung in Europa: Die Abrechnung mit Faschismus und Kollaboration nach dem zweiten Weltkrieg, ed. Klaus-Dietmar Henke and Hans Woller (Munich, 1991), 32-66; Clemens Vollnhals, ed., Entnazifizierung: Politische Säuberung und Rehabilitierung in den vier Besatzungszonen, 1945-1949 (Munich, 1991), 7-64; Peter Reichel, Vergangenheitsbewältigung in Deutschland: Die Auseinandersetzung mit der NS-Diktatur von 1945 bis heute (Munich, 2001), 30-37.

2 Theodor Veiter, Gesetz als Unrecht: Die österreichische Nationalsozialistengesetzgebung (Vienna, 1949); for Germany see Julius Fürstenau, Entnazifizierung (Berlin, 1969).

${ }^{3}$ Dieter Stiefel, Entnazifizierung in Österreich (Vienna, 1981).

${ }^{4}$ Ibid., 93 (table), 293-97. See also Manfried Rauchensteiner, Die Zwei: Die Große Koalition in Österreich, 1945-1966 (Vienna, 1987), 91-93; Hugo Portisch and Sepp

The Journal of Modern History 79 (September 2007): 572-612 (C) 2007 by The University of Chicago. 0022-2801/2007/7903-0003\$10.00 All rights reserved.
} 
Perhaps the main problem with this conservative position is its implication that traditional legal instruments were adequate to deal with the legacy of National Socialism in the actual circumstances of postwar Germany or Austria. This in turn rests on the assumption that by the end of the war Austrian society had undergone a profound educative process, which understates the involvement (to varying degrees of criminal culpability) of significant parts of Austrian society in Nazi rule. ${ }^{5}$ In the end this position sees the basic problem not as National Socialism but as denazification, a delusive process that somehow had to be got through before society could begin to function again. The victims of National Socialism too are displaced in this perspective by the objects of denazification, personified by the figure of the "small," misled "party comrade" (Parteigenosser). ${ }^{6}$

The "left-liberal" critique of denazification emerged in the 1960s as part of the New Left claim that an opportunity had been missed - that of establishing grassroots democracy in the ruins of the Third Reich. The anti-Communism of the Western occupation authorities, particularly that of the U.S. military, it was argued, had led them to stifle spontaneous, antifascist impulses "from below." However, the evidence for these impulses is thin for West Germany, where this claim was first advanced. It is equally thin for Austria, where such antifascist groups as did emerge at the end of the war (for example, the "O5" resistance group) were quickly absorbed into the three political parties that were (re)constituted (as "antifascist") in April 1945: the Socialist Party (SPÖ), the People's Party (ÖVP), and the Communist Party (KPÖ). Under those cir-

Riff, Österreich II: Der Lange Weg zur Freiheit: Die Wiedergeburt unseres Staates (Vienna, 1986), 56-83. For party membership figures (up to March 1943), see Gerhard Jagschitz, "Von der 'Bewegung' zum Apparat: Zur Phänomenologie der NSDAP im Dritten Reich, 1938-1945," in NS-Herrschaft in Österreich: Ein Handbuch, ed. Emmerich Tálos, Ernst Hanisch, and Wolfgang Neugebauer (Vienna, 2000), 88-122, 109.

${ }^{5}$ For a recent overview see Evan Bukey, Hitler's Austria: Popular Sentiment in the Nazi Era, 1938-1945 (Chapel Hill, NC, 2000).

${ }^{6}$ Stiefel, Entnazifizierung, 328-32; see also Dieter Stiefel, "Der Prozeß der Entnazifizierung in Österreich," in Henke and Woller, Politische Säuberung in Europa, 146. Empathy with the "victims" of denazification is even more evident in Lothar Höbelt, Von der vierten Partei zur Dritten Kraft: Die Geschichte des VdU (Graz, 1999); for detailed criticism see Robert Knight, "The Austrian State Treaty and Beyond," Contemporary European History 10 (2001): 132-38.

${ }^{7}$ Lutz Niethammer, Ulrich Borsdorf, and Peter Brandt, eds., Arbeiterinitiative, 1945: Antifaschistische Ausschüsse und Reorganisation der Arbeiterbewegung in Deutschland (Wuppertal, 1976); see also Rebecca Boehling, "U.S. Military Occupation, Grass Roots Democracy, and Local German Government," in American Policy towards Germany, 1945-1955, ed. Jeff Diefendorf, Axel Frohn, and Hermann-Josef Rupieper (Cambridge, 1993), 281-306. 
cumstances the claim that an antifascist opportunity was stifled by the (Western) Allies has been hard to sustain. ${ }^{8}$

Nevertheless, a wider left-liberal criticism of the reconstitution of the Austrian republic has gathered momentum in the last two decades, with the "Waldheim Affair" and the rise of Jörg Haider acting as catalysts if not triggers. ${ }^{9}$ There is now a considerable literature that emphasizes the continuities of popular prejudice (notably antisemitism), is deeply skeptical of earlier claims about national resistance and collective victimhood, and stresses postwar Austrian evasions. ${ }^{10}$ Some of this literature has been criticized as moralistic and self-righteous or condemned as unhistorical in that it judges the postwar

${ }^{8}$ See, among others, Robert Knight, "Britische Entnazifizierungpolitik," Zeitgeschichte 11 (1984): 287-301; Oliver Rathkolb, "US-Entnazifizierung in Österreich zwischen kontrollierter Revolution und Elitenrestauration (1945-1949)," Zeitgeschichte 11 (1984): 302-25; Sebastian Meissl, Klaus-Dieter Mulley, and Oliver Rathkolb, eds., Verdrängte Schuld-Verfehlte Sühne: Entnazifizierung in Österreich, 1945-1955 (Vienna, 1986); Winfried R. Garscha and Claudia Kuretsidis-Haider, Die Nachkriegsjustiz als nicht-bürokratische Form der Entnazifizierung: Österreichische Justizakten im europäischen Vergleich (Vienna, 1995), 18-22; Winfried Garscha, "Entnazifizierung und gerichtliche Ahndung von NS-Verbrechen," in Tálos et al., NS-Herrschaft in Österreich, 852-83; Brigitte Bailer-Galanda and Winfried Garscha, "Der österreichische Staatsvertrag und die Entnazifizierung," in Der österreichische Staatsvertrag, 1955: Internationale Strategie, rechtliche Relevanz, nationale Identität/The Austrian State Treaty, 1955: International Strategy, National Identity, ed. Arnold Suppan, Gerald Stourzh, and Wolfgang Mueller (Vienna, 2005), 629-54; see also Hubert Feichtlbauer's journalistic account, Der Fall Österreich: Nationalsozialismus, Rassismus; eine notwendige Bilanz (Vienna, 2000), 122-33.

${ }^{9}$ See Gerhard Sprengnagel and Gerhard Botz, eds., Kontroversen um Österreichs Zeitgeschichte: Verdrängte Vergangenheit, Österreich-Identität und die Historiker (New York, 1994); Heidemarie Uhl, "Zeitgeschichtsforschung und "österreichisches Gedächtnis,'” Zeitgeschichte 30 (2003): 341-56; Ingrid Bauer, "Kontinuitätaten und Transformation: Die österreichische Zeitgeschichtsforschung im Generationenvergleich," Zeitgeschichte 30 (2003): 320-40.

${ }^{10}$ See, among others, Walter Manoschek, "Verschmähte Erbschaft: Österreichs Umgang mit dem Nationalsozialismus, 1945 bis 1955," in Österreich, 1945-1995, ed. Reinhard Sieder, Heinz Steinert, and Emmerich Tálos (Vienna, 1995), 94-106; Ulf Brunnbauer, ed., Eiszeit der Erinnerung: Vom Vergessen der eigenen Schuld (Vienna, 1999); Peter Utgaard, Remembering and Forgetting Nazism: Education, National Identity, and the Victim Myth in Postwar Austria (New York, 2003); Walter Schuster and Wolfgang Weber, eds., Entnazifizierung im regionalen Vergleich, Archiv der Stadt Linz (Linz, 2004); Ernst Hanisch, Der Lange Schatten des Staates: Österreichische Geschichte, 1890-1990 (Vienna, 1994), 420-25; Klaus Eisterer, "Österreich unter Alliierter Besatzung," in Österreich im 20. Jahrhundert: Vom Zweiten Weltkrieg bis zur Gegenwart, ed. Rolf Steininger and Michael Gehler, vol. 2 (Vienna, 1997), 147-87, esp. 168-77; Martin F. Polaschek, Im Namen der Republik Österreich! Die Volksgerichte in der Steiermark, 1945 bis 1955, Veröffentlichungen des Steiermärkischen Landesarchives, vol. 23 (Graz, 1998); 
generation by the standards of a later one, instead of trying to understand it. ${ }^{11}$ Whether or not this criticism is valid in particular cases will depend on how "moralistic" is defined (it rarely is), but recent discussions suggest, if anything, a retreat from finger-pointing. ${ }^{12}$ One reason may be that a focus on the structural or mental continuities of Austrian society raises the difficult question of how a "society of perpetrators" (Tätergesellschaft) could ever have been expected to instigate a "self-cleansing." 13 And if it could not, what grounds are there for criticism?

This question of how a society can pull itself up by its own moral bootstraps takes us back to a famous argument made by Hermann Lübbe over twenty years ago. According to Lübbe, West German society had not repressed its complicity in National Socialism but rather had exercised a functionally necessary "communicative silence." By conforming outwardly to democratic norms the generation that had followed Hitler made any relapse impossible and took the first step toward genuine democracy. ${ }^{14}$ Lübbe's argument was directed against Alexander and Margarete Mitscherlich's diagnosis of West German society as one "incapable of mourning" and against their prescription of "working through" guilt and trauma. However, the Mitscherlichs' stress on the psychological costs of repression has been taken up more recently by Gesine Schwan, who argues that Lübbe's external conformity falls short of what familial and social relations in a democracy require.$^{15}$ For her it is the cost of repression that matters.

\footnotetext{
${ }^{11}$ For example, Gabriele Holzer, Verfreundete Nachbarn: Österreich-Deutschland ein Verhältnis (Vienna, 1995), 33-44; Rudolf Burger, "Irrtümer der Gedenkpolitik: Ein Plädoyer für das Vergessen,” Europäischer Rundschau 29, no. 2 (2001): 3-13.

${ }^{12}$ For example, Anton Pelinka, Out of the Shadow of the Past, Nations of the Modern World (Oxford, 1998), combines both "functionalist" and moral arguments. Oliver Rathkolb, Die paradoxe Republik: Österreich, 1945 bis 2005 (Vienna, 2005), stresses the continuities of popular prejudice, 392-405; Maria Mesner, ed., Entnazifizierung zwischen politischem Anspruch und Kaltem Krieg: Das Beispiel der SPÖ (Vienna, 2005), is concerned with the circumstances and costs of reintegration within the SPÖ.

${ }^{13}$ Martin Horvath, Anton Legerer, Judith Pfeifer, Stephan Roth, eds., Jenseits des Schlussstrichs: Gedenkdienst im Diskurs über Österreichs nationalsozialistische Vergangenheit (Vienna, 2002), 22-33.

${ }^{14}$ Hermann Lübbe, "Der Nationalsozialismus im politischen Bewußtsein der Gegenwart," in Deutschlands Weg in die Diktatur: Internationale Konferenz, zur nationalsozialistischen Machtübernahme, ed. Martin Broszat et al. (Berlin, 1983), 329-49.

${ }^{15}$ Alexander and Margarete Mitscherlich, Die Unfähigkeit zu trauern: Grundlagen kollektiven Verhaltens (Munich, 1977); Gesine Schwan, Politics and Guilt: The Destructive Power of Silence, trans. Thomas Dunlop (London, 1997)/Politik und Schuld: Die zerstörerische Macht des Schweigens (Frankfurt am Main, 1997), esp. 54-99, 13444, 177-79 [English ed.]; for Austria see Felix de Mendelssohn, "Psychoanalyse als Aufklärung," in Das Grosse Tabu: Österreichs Umgang mit seiner Vergangenheit, ed. Anton Pelinka and Erika Weinzierl (Vienna, 1987), 42-59.
} 
Helmut Dubiel has applied these arguments in his study of the debates of the German Bundestag. At first sight his position appears diametrically opposed to Lübbe's. ${ }^{16} \mathrm{He}$ sees self-critical scrutiny of guilt as an essential requirement for creating a democratic culture, and he finds its absence in the Bundestag debates of the 1950s repugnant, even baffling. The democracy that emerged in the 1960s was "only an institutional skeleton" that remained to be fleshed out. Nevertheless, his inability to imagine an alternative scenario and his conclusion that the necessary culture of reflection had to grow "in long and very complex civilizing processes" are in the end not as far from Lübbe as might be expected. ${ }^{17}$

For the historian all this suggests that the issue is not whether the integration of most former Nazis in post-Nazi society was inevitable. In some sense it clearly was. What matters more is the kind of integration that took place and the quality of the democratic culture that emerged as a result. ${ }^{18}$ Dubiel makes much here of the West German (forced) acceptance of the legal succession to the Third Reich. Put simply, West Germany's elites had nowhere to run. By contrast, the designation of Austria as "the first victim of Hitlerite aggression" (in the words of the 1943 "Moscow Declaration") gave Austria an escape route. Dubiel follows here the famous distinction made by the German sociologist M. Rainer Lepsius, who argued that while West Germany "internalized" its complicity and the German Democratic Republic "universalized" it, Austria was able to "externalize" it - that is, off-load it onto Berlin, thus evading discussion or critical reflection. ${ }^{19}$ Lepsius's brilliant analysis has been deservedly influential, but it also risks being misunderstood in two contrasting senses. On the one hand, it can encourage the cliché that Austrian evasions were the product of a particularly opportunistic or cynical national character. On the other, it can degenerate into a rather crude "realist" argument that the Austrian state acted no differently from other states in taking the "escape route" offered by the Moscow Declaration. Any other course would have been irrational. ${ }^{20}$

${ }^{16}$ Helmut Dubiel, Niemand ist frei von der Geschichte: Die nationalsozialistische Herrschaft in den Debatten des Deutschen Bundestages (Vienna, 1999).

${ }^{17}$ Ibid., 76, 289. For a similar though more positive discussion see Anne Sa'adah, Germany's Second Chance: Trust, Justice, and Democratization (Cambridge, MA, 1998), 135-42.

${ }_{18}$ Wolfgang Neugebauer and Peter Schwarz, Der Wille zum aufrechten Gang: Offenlegung der Rolle des BSA (Bund sozialdemokratischer AkademikerInnen, Intellektueller und KünstlerInnen) bei der gesellschaftlichen Reintegration ehemaliger Nationalsozialisten (Vienna, 2005).

${ }^{19}$ M. Rainer Lepsius, "Das Erbe des Nationalsozialismus und die politische Kultur der Nachfolgestaaten des 'Großdeutschen Reiches,'” in his Demokratie in Deutschland: Soziologisch-historische Konstellationsanalysen; Ausgewählte Aufsätze (Göttingen, 1993), 229-45: see Heidemarie Uhl, "Zeitgeschichtsforschung und 'österreichisches Gedächtnis,"' Zeitgeschichte 30 (2003): 341-56.

${ }^{20}$ For example, Michael Gehler, ed., Karl Gruber: Reden und Dokumente, 1945- 
In both cases, overstressing collective issues - "character" in the first, rationality in the second-diverts attention from an analysis of the premises, goals, and resources of the various actors involved and from their interactions.

This article attempts such an analysis by examining denazification in the southern Austrian province of Carinthia. Questions about Carinthia's democratic culture were raised sporadically after the war but have only reemerged since the electoral successes of Jörg Haider, who, despite recent setbacks nationally, remains governor of the province (at the time of writing). Part of the Carinthian electorate appears ready to overlook his defense of aspects of the Third Reich and his praise for those who fought for it in the Waffen-SS and elsewhere. ${ }^{21}$ Some see this as evidence that the province comes "from another galaxy." ${ }^{22}$ Others within the provincial establishment have defended the province against the accusation that it is especially "brown." ${ }^{23}$ Historical investigations of denazification in Carinthia have tended to adopt a provincial focus, seeing this as one of the many problems that beset the province, sometimes implying that Carinthia would have been better off left to its own devices. ${ }^{24}$ More critical studies, notably those of Alfred Elste and Dirk Hänisch,

1953: Eine Auswahl (Vienna, 1994), 18; Gerald Stourzh, Um Einheit und Freiheit: Staatsvertrag, Neutralität und das Ende der Ost-West-Besetzung Österreichs, 1945 1955 (Vienna, 1998), 20-28.

${ }^{21}$ See, among others, Ruth Wodak and Anton Pelinka, eds., The Haider Phenomenon in Austria (New Brunswick, NJ, 2002), 95-119. For a defense (in my view unconvincing) of Haider's comments, see Lothar Höbelt, Defiant Populist: Jörg Haider and the Politics of Austria (West Lafayette, IN, 2003), 34-37.

22 "SPÖ hilft Haider ins Amt," Der Spiegel, March 13, 2004.

${ }^{23}$ Claudia Fräss-Ehrfeld, "Das Kärntner Landesbewusstsein," in Kärnten: von der deutschen Grenzmark zum österreichischen Bundesland, ed. Helmut Rumpler (with assistance of Ulfried Burz), Geschichte der österreichischen Bundesländer seit 1945, vol. 6 (Vienna, 1998), 777-801; see also Claudia Fräss-Ehrfeld, "Zwischen Bundeskompetenz und Kärntner Realität: Die Kärntner Minderheitenproblematik in der Zweiten Republik, 1945-1976," in Kärnten und Wien: Zwischen Staatsidee und Landesbewusstsein, ed. Claudia Fräss-Ehrfeld and Helmut Rumpler, Kärnten und die Nationale Frage, vol. 4 (Vienna, 2005), 83-162.

${ }^{24}$ Wilhelm Wadl, "Entnazifizierung in Kärnten," in Schuster and Weber, Entnazifizierung, 251-66; August Walzl, Kärnten 1945: Vom NS-Regime zur Besatzungsherrschaft im Alpen-Adria-Raum (Klagenfurt, 1985), and Die Bewältigung: Nachkriegsjahre in Kärnten und Friaul (Klagenfurt, 1999), 198-209; Wilhelm Wadl, Das Jahr 1945 in Kärnten: Ein Überblick (Klagenfurt, 1985), and "Britische Besatzung in Kärnten und in der Steiermark bis zum Jahresende 1945," in Österreich 1945: Ein Ende und viele Anfänge, ed. Manfried Rauchensteiner and Wolfgang Etschmann (Graz, 1997), 24772, esp. 261. Other works on provincial denazification apart from Schuster and Weber, Entnazifizierung: Klaus Eisterer, Französische Besatzungspolitik: Tirol und Vorarlberg, 1945/46, Innsbrucker Forschungen zur Zeitgeschichte, vol. 9 (Innsbruck, 1992), 163-237; Kurt Tweraser, US-Militärregierung Oberösterreich, vol. 1, Sicherheitspolitische Aspekte der amerikanischen Besatzung in Oberösterreich-Süd, 1945-1950 (Linz, 1995). 
have investigated the deficiencies of denazification in the context of the reestablishment of Carinthian parties and have stressed continuities in attitudes and personnel. ${ }^{25}$

Any discussion of Carinthia needs to grapple with the highly elusive notion of Heimat. ${ }^{26}$ To oversimplify a complex discussion, the Carinthian Heimat has been defined for more than a century in two directions: against the capital and against the Slav world to the south. ${ }^{27}$ Vienna came to be blamed for many of the province's economic troubles, disliked as the capital of the Catholic multinational empire, and later, in the First Republic, feared as the Marxist, Jewish "Red Vienna." The Slav threat was seen as originating from beyond the Karawanken Mountains to the south, but it was also located in the Slovene minority living within the province after its leaders began to assert its collective rights in the decades before the First World War. When metropolitan institutions (e.g., the administrative court) gave (limited) support to these rights, both "anti-Carinthian" "threats" appeared to be reinforcing each other.

With the collapse of the Habsburg Monarchy, the struggle to delineate the border between Carinthia and the new South Slav Kingdom became intertwined (as it did in other borderland areas like Styria and Burgenland) with a struggle over the ethnic identity of the border population. In the end, the competition between ethnically and historically based claims was resolved in favor of the latter when an internationally supervised plebiscite in the south of the province in October 1920 produced a 60:40 vote for Austria and against Yugoslavia. As a result-in a mirror image of the Czech situation-almost all of the province's Slovene-speaking population (nearly thirty-five thousand according to the disputed 1923 census) remained in the province. What collective or individual rights they should enjoy became a central issue of provincial politics. For a range of German national parties, associations, and clubs the clear answer was that Carinthia was a bulwark of Deutschtum and the minority should assimilate or leave.

${ }^{25}$ Alfred Elste and Dirk Hänisch, Kärnten von der ersten zur Zweiten Republik: Kontinuität oder Wandel? (Klagenfurt, 1998), 39-41; Alfred Elste, Michael Koschat, and Hanzi Filipič, NS-Österreich auf der Anklagebank: Anatomie eines politischen Schauprozesses im kommunistischen Slowenien (Klagenfurt, 2000), 52-65; Alfred Elste, Kärntens braune Elite (Klagenfurt, 1997), 12-13.

${ }^{26}$ See Elizabeth Boa and Rachel Palfreyman, Heimat: A German Dream; Regional Loyalties and National Identity in German Culture, 1890-1990 (Oxford, 2000).

${ }^{27}$ The following summary owes much to Helmut Rumpler, "Die nationale Frage im Spannungsfeld von kärntnerischem Landespatriotismus, österreichischem Staatsbewusstsein und völkischem Nationalismus, 1918-1938," in Fräss-Ehrfeld and Rumpler, Kärnten und Wien, 9-82. See also Alfred Ogris, "Anschlussideen in Kärnten in der Zwischenkriegszeit (1918-1938)," in Das Jahr 1938 in Kärnten und seine Vorgeschichte: Ereignisse - Dokumente-Bilder, ed. Alfred Ogris and Wilhelm Wadl, Das Kärntner Landesarchiv, vol. 15 (Klagenfurt, 1988), 13-40. 
The goal of a German Heimat politics, as Helmut Rumpler has stressed, did not necessarily mean an Anschluss with Germany, but in the crisis-ridden and radicalized interwar period it frequently did. The more radical pan-Germanists gained ground, and even before Hitler seized power in Germany Carinthian National Socialists were able to capitalize on anti-Viennese and anti-Slav resentments. ${ }^{28}$ Despite setbacks after it was declared illegal in 1933, the party gained support among nearly all sections of society. The Anschluss itself has plausibly been called the victory of the provinces over Vienna. ${ }^{29}$ In the following years the Nazi state successfully fostered the mythology of the "defensive struggle" (Abwehrkampf) of 1918-19, in which Carinthia appeared as a bulwark of Deutschtum under threat from a devious Slav foe but neglected or abandoned by the capital. This underpinned a dual project: the expansion of German dominance to the south (after the invasion of Yugoslavia in April 1941 and the acquisition of "Upper Carniola" and other parts of Yugoslavia) and a push for the final elimination of Slovene language and culture within the province itself.

Four years later, denazification was therefore not merely a question of what to do about thousands of Nazi Party members (amounting to roughly a quarter of Carinthia's electorate). ${ }^{30}$ It was also centrally about how the values that had sustained the Heimat under Nazi rule could be reconciled with a democratic Austria.

${ }^{28}$ For Carinthian Nazis before the Anschluss see Ulfried Burz, Die Nationalsozialistische Bewegung in Kärnten (1918-1933): Vom Deutschnationalismus zum Führerprinzip, Das Kärntner Landesarchiv, vol. 23 (Klagenfurt, 1998); Alfred Elste and Dirk Hänisch, Auf dem Weg zur Macht: Beiträge zur Geschichte der NSDAP in Kärnten von 1918 bis 1938 (Vienna, 1997); Bruce F. Pauley, Hitler and the Forgotten Nazis: A History of Austrian National Socialism (Chapel Hill, NC, 1981), 131, 138-39; Helmut Rumpler and Ulfried Burz, eds., März 1938: Kärnten; Fallstudien und Dokumente zum Weg in den "Anschluss" (Klagenfurt, 1989); Ogris and Wadl, Das Jahr 1938. Nazi rule in Carinthia is notably underresearched, but see Stefan Karner, " “. . . des Reiches Südmark': Kärnten und Steiermark im 'Dritten Reich,' 1938-1945," in Tálos et al., NSHerrschaft in Österreich, 292-324. For Germanization and persecution of the Slovene minority, see Avguštin Malle, ed., Pregon koroških Slovencev, 1942-2002: Die Vertreibung der Kärntner Slowenen (Klagenfurt, 2002); Stefan Karner, "Die Aussiedlung von Kärntner Slowenen, 1942," in Aussiedlung_Verschleppung-nationaler Kampf, ed. Stefan Karner and Andreas Moritsch, Kärnten und die Nationale Frage, vol. 1 (Vienna, 2005), 21-51.

${ }^{29}$ The classic Austrian study is Ernst Hanisch, Gau der guten Nerven: Die nationalsozialistische Herrschaft in Salzburg, 1938-1945 (Salzburg, 1997), originally published as Nationalsozialistische Herrschaft in der Provinz: Salzburg im Dritten Reich (Salzburg, 1983); also Rumpler,"Nationale Frage,” 26.

${ }^{30}$ Membership had reached nearly forty-eight thousand in May 1943 (Jagschitz, "Von der 'Bewegung,", 515), not including “candidate members" (Parteianwärter) who may have amounted to a further ten thousand; see Stiefel, Entnazifizierung, 98; and Wadl, "Entnazifizierung," 254. 


\section{The HeImat From ThiRd ReICH to SECOND RePublic}

Nazi rule in Carinthia ended when the Gauleiter Friedrich Rainer finally resigned, only an hour before midnight on May 7, 1945. It came after negotiations with several pre-Anschluss politicians from the Social Democrats, Christian Socials, and Agrarian League (Landbund). The provisional government met for the first time the following morning. ${ }^{31}$ Only hours later, British and then Yugoslav forces arrived on the scene. ${ }^{32}$

It is hard to see this as the victory of a "resistance movement." ${ }^{33}$ According to the account left by Meinrad Natmeßnig, the chief civil servant of the Gau (Gauamtsdirektor), detailed planning for a transfer of power had not started until May 3, when Rainer discussed the "formalities of the hand-over of power" with his inner circle. Strikingly, the only group to which Natmeßnig was prepared to apply the label "resistance movement" were the Communists - the only group not admitted into the provisional government until after Rainer had left the scene. The other politicians, he recorded, were "quite unprepared to take over power" and at first unable to propose members of a provisional government. ${ }^{34}$ Given the success with which Nazi rule had functioned to the last this is hardly surprising. It is also consistent with the biographies of the other members of the government, as far as they are known. It would emerge two years later that the Social Democratic provisional governor Hans Piesch had probably been involved, albeit only in a middle-ranking po-

${ }^{31}$ For the sake of clarity this first government (which lasted from May 7 to June 6) will be designated PKLR (Provisorische Kärntner Landesregierung) 1, the second provisional government (recognized by the British) as PKLR 2 (July 24 to December 10), the intermediate "Consultative Committee" or Konsultativer Landesauschuss as KL (June 6-July 24), and the government formed after the elections of November 1945, the Kärntner Landesregierung, as KLR.

${ }^{32}$ See, among others, Walzl, Kärnten 1945, and Die Bewältigung, 198-209; Wadl, Das Jahr 1945; Hanns Haas and Karl Stuhlpfarrer, Österreich und seine Slowenen (Vienna, 1977), 88; Gabriela Stieber, Die Briten als Besatzungsmacht in Kärnten, 1945-1955, Das Kärntner Landesarchiv, vol. 31 (Klagenfurt, 2005), 37-55. For a vivid eyewitness account see Peter Wilkinson, Foreign Fields: The Story of an SOE Operative (London, 1997), 234-38.

${ }^{33}$ The term is used by, among others, Wadl, Das Jahr 1945, 30; Manfried Rauchensteiner, Der Sonderfall: Die Besatzungszeit in Österreich, $1945-1955$ (Graz, 1979), 86-87; Alfred Elste and Michael Koschat, "Kontinuität der politischen Eliten, 19181945," in Nationale Frage und Öffentlichkeit, ed. Werner Drobesch and Avguštin Malle, Kärnten und die Nationale Frage, vol. 2 (Vienna, 2005), 166.

${ }^{34}$ Meinrad Natmeßnig, "Erinnerung an die Geschehen Kärntens in den Tagen des Zusammenbruches Großdeutschlands, den schwersten Tagen in der Geschichte des Deutschen Reiches und den schicksalsschwerste Tage [sic] meines Heimatlandes Kärnten," (copy) n.d., Slovenski Znanstveni Inštitut (Archive of the Slovene Scientific Institute; ASZI), Celovec (Klagenfurt), C, XII. 
sition, in the implementation of Nazi racial policies ${ }^{35}$ Some of Carinthia's other "founding fathers" had also supported the Nazi regime. ${ }^{36}$ Several of the new leaders, however, both conservative and socialist (or Social Democratic), had been its victims. ${ }^{37}$ The most important of these was Ferdinand Wedenig, the socialist who in 1947 would succeed Piesch as governor. Between the poles of active collaboration and imprisonment were several government members, probably the majority, who had simply kept their heads down, continued to work, and survived. ${ }^{38}$

If these politicians had a common cause it was the defense of Carinthia against the rapidly approaching Yugoslav forces. The "idiom" of Heimat might in principle, as Celia Applegate has argued for another locality, have been able to embody "the political and social community that could be salvaged from the Nazi ruins." 39 But if that community was to be based on a democratic

${ }^{35}$ William Mack (British minister, Vienna), writing to Bevin (March 14, 1947, Public Record Office [PRO], FO371/63958/C44376), reported that it had emerged that Piesch had worked in a "Race Office" that "dealt with the expropriation of Jews and the confiscation of their property as well as of the Resettlement Office, which was concerned with exchanges of population and attendant property questions in Carniola [Krain]." See also Ministry of Foreign Affairs of the Federal People's Republic of Yugoslavia, ed., Documents on the Carinthian Question (Belgrade, 1948), docs. 31, 32. See also Elste and Hänisch, Kärnten von der ersten zur Zweiten Republik, 57, 309, who question the extent of Piesch's complicity.

${ }^{36}$ For example, Wolfram Enzfelder, now responsible for Social Administration (Soziale Verwaltung), had worked as a journalist for the official Gau newspaper, the Kärntner Grenzruf. See Robert Buchacher, "Die Tages- und Wochenpresse des Bundeslandes Kärnten von der Gründung der Republik bis zur Gegenwart (1918-1973)” (PhD diss., University of Vienna, 1973), 226. Julius Lukas junior had become a Nazi Party member in May 1940. He was forced to resign in February 1946 (Berlin Document Centre, File on Julius Lukas; Political Report Kärnten, September 1946 and January 1947, PRO, FO1007/335).

${ }^{37}$ For an example of a conservative leader, there is the former Christian Social Alois Karisch, who was to become head of the Carinthian People's Party and deputy governor. See Rumpler, März 1938, 295. Sylvester Leer had been a Christian Social member of the Landtag and a leading opponent and target of the Nazi Party before 1934. See Rudolf Freisitzer, "Der Beginn des NS-Terrors," in Rumpler, März 1938, 6, 216; Elste and Hänisch, Auf dem Weg, 213, 219, 230. On Ignaz Tschurtschentaler see Rumpler, "Der nationale Dammbruch nach dem Juliabkommen des Jahres 1936; Die politische und wirtschaftliche Situation Kärntens in Vorfeld des 'Anschlusses'," in Rumpler and Burz, März 1938, 14-31, 16; Freisitzer, "Beginn,” 216-17, 297. Some Socialist leaders, like Anton Falle, had died in concentration camps; others, like Hans Lagger, returned, physically damaged, but continued to pursue political careers in minor positions.

${ }^{38}$ This probably applies to Hans Herke, Julius Santer, Josef Ritscher, Karl Perchtold, and Hans Ferlitsch.

${ }^{39}$ Celia Applegate, A Nation of Provincials: The German Idea of Heimat (Berkeley, 1990), 242. 


\section{Knight}

reorientation, some scrutiny of how the Heimat had become implicated in the Nazi project was surely required. Beyond occasional general references to avoiding past mistakes there was almost no sign of this in Carinthia. On the contrary, the Heimat idiom helped ease the transition from the Nazi regime to its successor. For example, Rainer had insisted in his negotiations with the politicians that the ideals of the 1918-19 Abwehrkampf (defensive struggle) had to be represented in any body that succeeded him. The politicians had reassured him that they had always stood by the principle of "a free and undivided Carinthia" (Kärnten frei und ungeteilt). To protect the border Rainer proposed setting up a "League of Defenders of the Border" that should be organized in a way that would avoid the charge of being "a camouflaged SA or something similar." In response the politicians assured him that only the district leaders (Kreisleiter) were unacceptable as "fighters" (for the border) and that only Nazis who had violated the law would be punished. No one would be punished purely on the ground of party membership. Piesch promised that "we will ... only implement personnel changes, and these won't be done quickly." Rainer then promised that "the fighting forces of the party would not oppose the new regime" and declared himself ready to help to preserve the unity of the province. ${ }^{40}$ The unity of the province was duly featured in Rainer's valedictory radio speech, Natmeßnig's public statement, and the first declaration of the new government, all of which were published the next day. The government mentioned legal proceedings against the guilty but ruled out purges for the mass of party members. ${ }^{41}$ All this shows how, even before Nazi rule had ended, mobilization behind the Heimat undercut denazification. By contrast Piesch was soon rewriting the end of the Nazi regime as a Carinthian "self-liberation," with the implication that no further purges were required. ${ }^{42}$

How loyalty to Carinthia outweighed involvement in National Socialism can be seen in the case of Natmeßnig himself. Having initially been included in the provincial government, he was arrested by the British. ${ }^{43}$ Six weeks later the bank that had earlier employed him (the Klagenfurt Gewerbe- und Handelsbank) lobbied the provincial government to press for his release, arguing that "as a leading Bank director he could put his great knowledge and abilities in the service of the economy of Carinthia." In the ensuing discussion Natmeßnig's past efficiency and promotion of the province's interests were cited in mitigation of his responsibility for serving the Nazi state. Though some

${ }^{40}$ Natmeßnig, "Erinnerung”; "Kärnten—ein freies Land Österreichs!” Kärntner Zeitung, May 8, 1945; Elste and Hänisch, Kärnten von der ersten zur Zweiten Republik, 55 n. 165; and Elste, Koschat, and Filipič, NS-Österreich, 131.

${ }^{41}$ See, among others, Haas and Stuhlpfarrer, Österreich, 88; Elste, Koschat, and Filipič, NS-Österreich, 130 n. 523.

${ }^{42}$ KL 5th session, June 20, 1945, Kärnter Landesarchiv, Landesamtsdirektion [hereafter KLA, LAD]; see also Stieber, Die Briten, 106 n. 53.

${ }^{43}$ Walzl, Kärnten 1945, 249. 
doubts were expressed, the government backed the request for his release. ${ }^{44}$ Natmeßnig's past service to Carinthia was divorced from the regime it had supported. The "depoliticization" of the Heimat was thus itself a highly political process.

In the following years, loyalty to the Heimat remained a central rhetorical category in Carinthian politics. With it came a fundamental polarization: on one side stood the Carinthian parties, supposedly united in defense of the province; on the other, Carinthia's enemies. In this division those Slovenes who were ethnically conscious were liable to be considered traitors. Behind this view lay the widespread feeling (noted in an Office of Strategic Services [OSS] report of July 1945) that the minority "deserved and continues to deserve no better fate than absorption into the superior German community." 45

\section{BRITISH AND CARINTHIAN DENAZIFICATION}

The British occupation regime, which began shortly after the Carinthian provisional government was formed and continued - at least on paper-until 1955 , never seriously attempted to change the values of the society it was responsible for. Admittedly, Austria would need to be separated from Germany, to prevent any future Anschluss or revival of National Socialism, but that policy should, where possible, be implemented by working with, not against, the grain of Austrian society. ${ }^{46}$ Tension between the two aims was already implicit in the Moscow Declaration, which had not only proclaimed Austria to have been a victim of "Hitlerite aggression" but also warned that account would be taken of the fact that it had fought "as an integral part of Hitlerite Germany." In the eighteen months that elapsed between the declaration and the end of the war it had become clear that Austrian national identity had not been strong enough to inspire significant resistance. To that extent the case for

${ }^{44} \mathrm{KL}^{\text {th }}$ session, June 20, 1945, KLA, LAD.

${ }^{45}$ Research and Analysis Report 19, Johnson, July 6, 1945, in Siegfried Beer, "Kärnten im Frühsommer 1945: Drei Berichte und Analysen des Amerikanischen Geheimund Nachrichtendienstes OSS zu Politik, Wirtschaft und Gesellschaft in einem britischbesetzten Bundesland," in Carinthia I, 177 (1987): 433-36, 426 (author's translation back into English). For minority politics see Theodor Domej, "Der Konflikt nach dem Krieg," in Austria Slovenica: Die Kärntner Slovenen und die Nation Österreich/Koroški Slovenci in avstrijska nacija, ed. Andreas Moritsch (Klagenfurt, 1996), 86-165.

${ }^{46}$ For British denazification policy in Austria in general, see Knight, "Britische Entnazifizierungspolitik"; Siegfried Beer, "Die Briten und der Wiederaufbau des Justizwesens in der Steiermark, 1945-1950," in Die "britische" Steiermark 1945-1955, ed. Siegfried Beer (Graz, 1995), 111-40; Wolfgang Muchitsch, "Das Volksgericht Graz, 1946-1955," in Beer, Die "britische" Steiermark, 141-56; Siegfried Beer, "Die britische Entnazifizierung in Österreich, 1945-1948," in Schuster and Weber, Entnazifizierung, 399-430; Stieber, Die Briten, 171-82, 237-40. 
an interventionist occupation might appear stronger at the end of the war than it had in Moscow. At any rate, by May 1945 a denazification policy similar to that applied in Germany was probably inevitable. ${ }^{47}$ Intervention was also supported by the British legal view that - whatever the ambiguities of its situation-Austria was to be occupied as a (part of a) defeated enemy. British troops officially entered Austria "as victors, inasmuch as Austria has waged war as an integral part of Germany against the United Nations." ${ }^{48}$

However, although the denazification guidelines of the British military broadly followed those of the U.S. Counter-Intelligence Corps, British officials already had strong reservations about their wide (and ever-expanding) scope. Some of these sprang from an awareness of the financial and logistical pressures on the British economy and its global commitments. In this context, Austria was hardly a major priority and reeducating Austrians even less so. The view in Whitehall was that Austria's long-term future and its separation from Germany could be secured only by cultivating the "tender growth of Austrian independence," by avoiding the social and political divisions that had plagued the First Republic, and above all by creating a prosperous international economic environment. ${ }^{49}$ This pointed away from a punitive approach and toward conciliation and collaboration.

As far as Austria's provinces were concerned, British planners recognized that the attractions of "pan-Germanism" for the provincial middle classes had been one reason why Austrian statehood had failed. But so long as this did not lead to a renewal of an Anschluss movement the "internal" implications of pan-Germanism were not taken very seriously. British officials and soldiers were generally oblivious to the depth of ethnic tension in the area. They tended to think that differences could be defused by common sense or by "knocking heads together." As it became clear that neither Yugoslav territorial claims to southern Carinthia nor irredentism within the minority would be deflected, most came to see the minority simply as a security danger to be dealt with by security measures. ${ }^{50}$

${ }^{47}$ See Lothar Kettenacker, Krieg zur Friedensicherung: Die Deutschlandplanung der britischen Regierung während des Zweiten Weltkrieges (Göttingen, 1988), 353-73; Ian Turner, "Denazification in the British Zone," in British Occupation Policy and the Western Zones, 1945-1955, ed. Ian Turner (Oxford, 1989), 239-70.

${ }^{48}$ First proclamation reprinted in Gary Travers Grayson Jr., Austria's International Position, 1938-1945: The Re-establishment of Independent Austria (Geneva, 1953), 192-93; see also Wadl, Das Jahr 1945, 35; Stieber, Die Briten, 68-71.

${ }^{49}$ Report of the Interdepartmental Committee on Postwar Economic Policy toward Austria, Armistice Terms and Postwar Planning Committee (APW) (44) 93, September 22, 1944, PRO Cabinet Office Papers (CAB) 87/68.

${ }^{50}$ See Robert Knight, "Ethnicity and Identity in the Cold War: The Carinthian Border Dispute," International History Review 22 (2000): 274-303; Stieber, Die Briten, $295-326$. 
The British decision to work with the Carinthian provisional government that they found in situ amounted to an early prioritizing of collaboration over intervention. Jack Nicholls, the senior British diplomat attached to the Eighth Army, described the government as "precisely the sort of reasonably representative security-checked body" the Foreign Office had wanted to see in place in Austria as a first step toward the reestablishment of full democracy. Overall, the government was a "reasonably solid firm and anxious to cooperate with us." Piesch himself appeared "genuine and not too clever" (for Nicholls, this was clearly a recommendation). ${ }^{51} \mathrm{~A}$ fortnight after the government's formation one official did express fear that the "Piesch Party" might be "suspect to a large degree owing to it having been formed before our arrival," but this concern was brushed aside; since the provisional government had in effect already been recognized by the military government there would be "confusion if we now go back on this." It was decided to approve the Carinthian body as an interim solution "until popular wishes become clearer." 52 Admittedly, it was also decided to downgrade it temporarily to the status of an "advisory committee" without executive functions, but this was a secondary and temporary measure. ${ }^{53}$ The important point was that by accepting Carinthian "collaborators" the British inaugurated a relationship of mutual dependence; the British had the coercive means to arrest, dismiss, or intern, but since they did not have the resources or the will to govern at the point of bayonets they became dependent on the Carinthians.

In his opening speech to the Carinthian Advisory Committee (Konsultativer Landesauschuss), Colonel Donald Smith (senior military government officer) stressed the twin goals of restoring an administration that stood above politics and "ensuring that the Nazi element is eliminated." ${ }^{54} \mathrm{He}$ evidently saw no contradiction between the two goals, yet the conflict soon emerged in two senses. First, the tension between the "administrators" and the "denazifiers" became a permanent feature of the first year of military government, ${ }^{55}$ Second, for Carinthian politicians both administrative appointments and denazification were inextricably part of politics.

${ }^{51}$ Nicholls (c/o 5 Corps) to Hughes (ACABE), Rome, May 21, 1945, PRO, FO1020/ 977 (Nicholls's emphasis); see also Stieber, Die Briten, 71.

52 Hughes to Nicholls, May 26, 1945, Nicholls to Hughes, May 26, 1945, PRO, FO1020/977.

${ }^{53}$ See Memorandum, Powers of Provisional Governments in Styria and Carinthia, Deputy Commissioner Conference/Paper (DCC/P) (45) 13, July 31, 1945, PRO, FO371/46611/C4327. Many Carinthian authors overestimate the importance of the demotion, e.g., Walzl, Kärnten 1945, 266-67; Wadl, "Britische Besatzung," 254; Stieber, Die Briten, 71-75.

${ }^{54}$ Smith speech (German trans.), n.d., PRO, FO1020/976.

${ }^{55}$ Cullis minute, August 28, 1945, PRO, FO371/46649/C5088. 
The "denazifiers" in the Intelligence, Public Safety, and Field Security sections proceeded on the basis of the official guidelines. These laid down formal criteria for mass dismissal, arrest, and internment on the basis of rank and position in Nazi party or state organizations ("category arrests"), as well as allowing for "discretionary arrests" in a small number of situations. Decisions were to be made on the basis of the famous (or notorious) questionnaires (Fragebögen)..$^{56}$ By February 1946, 6,413 people had been arrested (in Styria and Carinthia and the British zone of Vienna combined). ${ }^{57}$ Most of them, including a large number of senior Nazi officials in the Gau administration, were held in the internment camps of Weissenstein and Wolfsberg. ${ }^{58}$ In addition, 23,789 Fragebögen had passed through the military government's hands (in all its Austrian occupation zones), leading to approximately 18,500 employment certificates being issued (3,032 were turned down). ${ }^{59}$

For all this activity, denazification soon faced the same problems that it did in Germany. Criticism mounted both inside and outside the military government. Most of it boiled down to the charge that official instructions were too formalistic and crude to assess how individuals had actually behaved in the Third Reich. ${ }^{60}$ One report argued that "the expression 'dangerous Nazi' is one incapable of definition and least of all of definition by categories" since it "could not adequately encompass the different degrees of commitment to Nazism." ${ }^{11}$ Several criticized the failure to arrest local industrialists who had backed the Nazi Party economically in its illegal period before the Anschluss and profited from the war economy without necessarily becoming party members.

For some of those responsible for denazification these weaknesses were an

${ }^{56}$ Allied Forces Headquarters [AFHQ], Counter Intelligence/Security Instruction (Austria) no. 2 (Vetting/Screening of Allied Employees in Austria), May 2, 1945, and $\mathrm{CI} /$ Security Instruction (Austria) no. 6 (Arrestable Categories in Austria), May 24, 1945, Instruction no. 29 (including tables A-D), May 28, 1945, PRO, FO1020/1097; see also Garscha, "Entnazifizierung," 855-57.

${ }^{57}$ Philip Nicholls to Bevin, February 5, 1946, PRO, FO371/55158/C1890. Of these 5,883 had been "category arrests."

${ }^{58}$ See list ("Verzeichnis") n.d [presumably February 1946], Österreichisches Staatsarchiv, Archiv der Republik [hereafter ÖStA, AdR], Bundeskanzleramt [BKA], Entnazifizierung, box 22 .

${ }^{59}$ Political Report, February 1946, PRO, FO1007/335.

${ }^{60}$ Area Security Office, Carinthia District, July 19-26, 1945, PRO, WO170/7144. See also Consolidated Intelligence Report [hereafter CIR] 9, September 19, 1945, CIR 11, October 3, 1945, published in Gabriela Stieber, ed., Consolidated Intelligence Reports: Psychological Warfare Branch; Military Government Kärnten, Mai 1945 bis April 1946, Das Kärntner Landesarchiv, vol. 32 (Klagenfurt, 2005), 158, 182; also Beer, "Kärnten im Frühsommer 1945"; Eisterer, Französische Besatzungspolitik, 189.

${ }^{61}$ Joint Weekly Intelligence Summary (JWIS) 10, September 7, 1945, PRO, FO371/ 46651/C6378. 
argument for extending the purge to those who had provided economic support for National Socialism. ${ }^{62}$ For the "administrators," however, they strengthened the case for allowing more flexibility for qualified experts (especially within the administration of justice and education). As one official (of the Economic Division) put it, "all the available brains were wanted" to get Austrian industry working again. ${ }^{63}$ From this perspective, purges were an irritant or worse. An education official complained that Public Safety interventions could mean that "the first thing they knew, the school was without a teacher." 64 In the administration of justice the objections of senior British officials to the removal of judges and state prosecutors later led to a common front with Austrian officials in the Justice Ministry. ${ }^{65}$ Several illegal Nazis were retained as judges and prosecutors. British justice officials themselves conceded that "we have laid somewhat more emphasis on the efficiency of the machine than Intelligence Organization, with their emphasis on denazification at the expense of efficiency, would have done themselves." 66

Almost from the start denazification had involved Carinthian politicians as advisers. Now, in response to criticism and the bureaucratic pressures, their role was extended. ${ }^{67}$ The rationale was that Carinthian politicians possessed the kind of local knowledge that could mitigate the crude formalism of the Fragebogen system. What this overlooked was that Carinthian politicians had different assumptions and a different agenda. Admittedly, they too wished to "get things moving" and like British administrators were irritated by the actions of the intelligence organizations. ${ }^{68}$ But even more important, denazification was subordinated to party competition, and after four years of authoritarian dictatorship and seven years of Nazi rule this was now gathering momentum. ${ }^{69}$ Party politics transformed denazification from a policy for determining who was to be purged (or punished) into a contest about who should be exempted.

Neither attachment to the Carinthian Heimat nor the proverbial Geist der

${ }^{62}$ Weekly Security Intelligence Report (WSIR) 5, August 3, 1945, PRO, FO371/ $46611 / \mathrm{C} 4833$.

${ }^{63}$ Piggott, British Standing De-Nazification Committee (BSDC), 3rd meeting, November 27, 1945, PRO, FO1007/412.

${ }^{64}$ BSDC, 3rd meeting, November 27, 1945, PRO, FO1007/412; Stieber, Die Briten, 237-40. For a similar analysis see Beer, "Die britische Entnazifizierung," 412-23.

${ }^{65}$ See Area Security Office, Carinthia, October 1945. PRO, WO170/7144; CIR 10, September 26, 1945, in Stieber, Consolidated Intelligence Reports, 173; Polaschek, Volksgerichte, 18-30; Beer, "Die britische Entnazifizierung," 418-19.

${ }^{66}$ Memorandum, Bulger Ministry of Justice Control Branch (LEGDIV), March 1, 1946, PRO, FO1020/1979.

${ }^{67}$ See, e.g., Public Safety Office Wolfsburg, May 18, 1945, PRO, FO1020/2881.

${ }^{68}$ See Beer, "Die britische Entnazifizierung," 415.

${ }^{69}$ In general see Knut Lehmann-Horn, "Die Macht der politischen Parteien," in Rumpler, Kärnten, 215-67. 
Lagerstrasse - that is, a cross-party spirit of unity forged in the crucible of shared suffering in Nazi concentration camps - could create a cross-party consensus on whom to exempt. For many socialists the memory of their persecution before 1938 remained fresh. The fact that their persecutors might themselves have suffered subsequently under Nazi rule did not cancel it out. ${ }^{70}$ Their conservative opponents were acutely aware of the weakness of the Christian Socials in a province where anticlerical traditions were so strong. The (qualified) turning away from political Catholicism by the People's Party was meant to broaden its appeal nationally, and the decision to merge with the German national and anticlerical Landbund (Agrarian League) was intended to achieve this by attracting non-Catholic conservative or "anti-Marxist" voters. But in Carinthia it also brought the socialists a chance to win support from those voters who continued to be suspicious of the People's Party's links with the Catholic Church and who were still resentful of the Dollfuss-Schuschnigg regime. ${ }^{71}$

In this competition neither party was willing to do without former Nazi Party (NSDAP) members. As elsewhere in Austria, the Socialists considered they were at an unfair disadvantage to their conservative rivals who could recruit from Catholic fraternities (in the Cartellverband)..$^{72}$ Some of their old members had gone over to the Nazi Party before the Anschluss or had come round to support it afterward. ${ }^{73}$ Others had been conscripted and killed in action or imprisoned. In June 1945 the first Socialist provincial conference (Landesparteikonferenz) decided that NSDAP members could join as "supporting members" (unterstützende Mitglieder). It was the start of an intense recruitment drive. ${ }^{74}$

The British decision to rely on Piesch gave the Socialists a head start in personnel decisions. These included hiring for positions not only in public administration but also in the teaching profession, which had strong German national and anticlerical traditions and where the level of Nazi membership

${ }^{70}$ See, e.g., CIR 10, September 7, 1945, in Stieber, Consolidated Intelligence Reports, 176.

${ }^{71}$ Werner Drobesch, "Die Geschichte der Kärntner ÖVP, 1945-1994," in Die Volkspartei-Anspruch und Realität: Zur Geschichte der Geschichte der ÖVP seit 1945, ed. Robert Kriechbaumer and Franz Schausberger (Vienna, 1995), 399-424; Dieter Binder, "'Von der "Rettung des christlichen Abendlandes" zu "Europa in uns": Die österreichische Volkspartei nach 1945," in Christdemokratie in Europa im 20. Jahrhundert, ed. Michael Gehler, Wolfram Kaiser, and Helmut Wohnout (Vienna, 2001), $399-424$.

${ }^{72}$ Neugebauer and Schwarz, BSA.

${ }^{73}$ See for the Vienna socialist party Matthew Berg, "Die SPÖ und die Praxis der Entnazifizierung," in Mesner, Entnazifizierung, 146-85.

${ }^{74}$ CIR 1, July 19, 1945, in Stieber, Consolidated Intelligence Reports, 90-91; Elste and Hänisch, Kärnten von der ersten zur Zweiten Republik, 21-35, 43, 65-68. 
had been high. ${ }^{75}$ On the opposite side of the party divide, the People's Party was ready to call for purges in public service but resisted pressure to dismiss Nazi members in the conservative strongholds of the farming organization (Bauernschaft), business, and banking. Their leader, Hans Ferlitsch, warned of the dire consequences of purging the farming organization and claimed, rather contradictorily, that without outside interference it would have long since been "cleansed." 76

Both sides criticized the British for inept or unjust decisions. ${ }^{77}$ But it would be wrong to conclude that a collective Carinthian wish to implement a more sweeping purge was being thwarted by the occupiers. What politicians of both parties clearly did want was more freedom to appoint or exempt within their own fiefdoms. The frequently expressed concern for the individual rights of the denazified, including the right of appeal in order to mitigate the formalism and unfairness of the Fragebogen system, can also be seen in this light. ${ }^{78}$ At the same time there was room for bargaining between the two parties, as in one case where the appointment of a Socialist candidate as mayor was offset by an agreement that his deputy should be taken from "the bourgeois group." 79 Such ad hoc arrangements pointed to the future development of Austria's Proporz system-but the point here is that they were rarely accompanied by scrutiny of individual culpability.

In the course of the summer of 1945 the role of Carinthian politicians expanded, and so did their self-confidence. ${ }^{80}$ The government was given a central role in the appointments first of mayors and chief district civil servants $(B e-$ zirkshauptleute), then of village councilors. ${ }^{81}$ At the start of September a new

${ }^{75}$ Smith speech (German version, n.d.), PRO, FO1020/976; Richardson, "Report on Visit to Kärnten, Review of Educational Situation," June 4, 1945, PRO, FO1020/2817; Stieber, Die Briten, 237-40; Herman Gruber, Die Jahre in der Politik: Erinnerungen (Klagenfurt, 1982), 47-49. Ulfried Burz, "Der Wille der Lehrerschaft ist der Wille des Volkes.: Bildungspolitische Zielsetzungen und Aktivitäten der nationalsozialistischen Bewegung in Kärnten," in Zur Geschichte des österreichischen Bildungswesens: Probleme und Perspektiven der Forschung, ed. Elmar Lechner, Helmut Rumpler, and Herbert Zdarzil (Vienna, 1992), 498-514.

${ }^{76} \mathrm{KL} 5^{\text {th }}$ session, June 20, 1945, KLA, LAD. See Elste and Hänisch, Kärnten von der ersten zur Zweiten Republik, 46-47, 103.

${ }^{77}$ See, e.g., Stieber, Die Briten, 179.

${ }^{78}$ See Amschl's comments to KL 5th session, June 20, 1945, KLA, LAD. The claim by Elste and Hänisch, Kärnten von der ersten zur Zweiten Republik, 137, that Amschl had himself been a party member appears to be based on a confusion of names since they refer to a Hans Amschl born September 21, 1909, whereas the politician Hans Amschl was born on October 29, 1896.

${ }^{79}$ KL 5th session, June 20, 1945, KLA, LAD.

${ }^{80}$ Ibid. See also CIR 4, August 14, 1945, in Stieber, Consolidated Intelligence Reports, 120-21.

${ }^{81}$ Military Government ordinance no. 29, KL 5th session, June 20, 1945, KLA, LAD; 
system of vetting and appointment was announced. Commissions representing the three authorized "antifascist" parties and chaired by a civil servant were to vet and then dismiss or confirm appointments for the lower levels of the civil service (below the Third Grade/Dienstgrad III). ${ }^{82}$ Advisory committees in each district were to make recommendations on the arrest of persons still at liberty, the release of those interned, and the reinstatement and dismissal of officials. The edifice was to be topped by a provincial advisory commission (Landesberatungskommission). ${ }^{83}$

British Intelligence argued that the new system would mean that those with local knowledge would now be able to pick out the "real Nazis." However, the linkages between denazification and political patronage became even more evident as provincial and national elections approached. At first it was widely assumed that most, perhaps all, former Nazi Party members would be allowed to vote. ${ }^{84}$ The efforts of the parties to woo them were probably only partly nullified by the decision to exclude all Nazi Party members from the franchise, since the exclusion was only partially enforced and in any case did not affect families and sympathizers. ${ }^{85}$ Uncertainties about the electoral roll, migration, and other imponderables make it impossible to say with any conviction how this affected the election result of November 26, 1945. What is undeniable is that the SPÖ victory in Carinthia represented a massive improvement on their best prewar performance (from 31.5 to 42.8 percent of the electoral roll, representing about twenty thousand more votes). Over half of these may have come from outside traditional socialist or Communist constituencies. ${ }^{86}$

Memorandum Bell (Govt. Branch) Allied Commission for Austria, British Element, Rome, July 10, 1945, and Brown (Internal Affairs Division), July 12, 1945, PRO, FO1020/975.

${ }^{82}$ Erlass Nr 12 ("Die Säuberung gewisser Verwaltungszweige von Nationalsozialisten”), KLA, Erlässe (English version: decree no. 12, PRO, FO945/50); Stieber, Die Briten, 176.

${ }^{83}$ PKLR 2, 17th session, October 31, 1945, KLA, LAD.

${ }^{84}$ For example, Newole (who as provincial chief civil servant had responsibility for drawing up electoral rolls) expected that "harmless" party members (whom he estimated at perhaps 80 percent of the total) would be allowed to vote: CIR 11, October 3, 1945, in Stieber, Consolidated Intelligence Reports, 182.

${ }^{85}$ Ludwig Reichhold, Geschichte der ÖVP (Graz, 1975), 122-23; Rauchensteiner, Sonderfall, 130. See CIR 16, November 8, 1945, in Stieber, Consolidated Intelligence Reports, 230; also Brigitte Bailer-Galanda, Die Entstehung der Rückstellungs- und Entschädigungsgesetzgebung: Die Republik Österreich und das in der NS-Zeit entzogene Vermögen, Österreichische Historikerkommission, vol. 3 (Vienna, 2003), 44.

${ }^{86}$ See Elste and Hänisch, Kärnten von der ersten zur Zweiten Republik, 186-87, 198-200 (tables 5.3, 5.4), who estimate that only 48 percent of SPÖ voters may have voted Socialist or Communist in 1930 and that 32 percent of those who had voted Nazi in 1930 may have voted SPÖ in 1945. However, as the authors make clear, these estimates have to be treated with extreme caution. See also Lehmann-Horn, "Macht," $218-19$. 
With half the total seats in the provincial Landtag (18 out of 36) behind him, Piesch was appointed governor, and Carinthia became (apart from the "city-province" of Vienna) Austria's only "red" province. This meant a further increase of SPÖ patronage in the public sector and an increase in the party's self-confidence in asserting its agenda against what was increasingly seen as British "tutelage." As for the new British denazification "system," its work, when it finally began, showed how wide the gulf was between British and Carinthian expectations. The committees concentrated heavily on recommending the reinstatement of those dismissed or the restoration of their pension rights. ${ }^{87}$ Similarly, the appointment by the Carinthian government of Paul Jobst as "denazification commissar" responsible for the "direction and monitoring of all denazification measures" was not so much an attempt to increase the tempo of denazification as to assert Carinthian-and SPÖ-control over it. ${ }^{88}$ Jobst complained of British tutelage while still combating in the press the persistent allegations that Carinthia was particularly "brown." the committees was ascribed by one senior British intelligence officer to his belief that "the Austrians feared to denounce prominent Nazis in case they should suffer for their action when the Allies had withdrawn. This was in itself an indication that denazification had not gone far enough - more particularly ... in the case of prominent industrialists and financiers." ${ }^{\circ 0}$ Others saw it as a "cultural" problem - the intrusion of party politics and patronage into an area that, as Smith had urged, should have been above politics. ${ }^{91}$

These and other diagnoses were aired within the upper echelons of the military government in a confused and sometimes ill-tempered discussion. Colonel Block (senior military government officer for Styria) tried to clarify British policy by laying down procedures for both integration and punishment. He advocated deporting the "real bad hats" to North Africa or elsewhere and warned dramatically that "the stage is set for history to repeat itself." In conclusion he recommended, first, "an Allied Proclamation stating that we intend to retain control for at least a decade" and, second, "a strong constructive handling of the Nazis." Otherwise, "if we leave behind the possibility of a

${ }^{87}$ See, inter alia, CIR 26, January 16, 1946, in Stieber, Consolidated Intelligence Reports, 348-49.

${ }^{88}$ KLR 5th session, January 23, 1946, KLA, LAD; CIR 27, January 23, 1946, in Stieber, Consolidated Intelligence Reports, 357; KLR 15th session, April 10, 1946, KLA, LAD. See also Jobst's comments in KLR 24th session, May 31, 1946, KLA, LAD.

${ }^{89}$ Paul Jobst, "Souveränität und Unzufriedenheit," Die Neue Zeit, January 13, 1946, "Kuratel oder Kontrolle," Die Neue Zeit, January 20, 1946, and "Das 'braune' Kärnten?" Neue Zeit, March 10, 1946.

${ }^{90}$ Gibson, BSDC, 5th meeting, January 8, 1946, PRO, FO1007/413, cited in Knight, "Entnazifizierungspolitik," 291-92; Beer, "Die britische Entnazifizierung," 419-20.

${ }^{91}$ Turton, "Report on Tour of Kärnten," January 4, 1946, PRO, FO1020/2033. 


\section{Knight}

Nazi come-back, we shall not properly have won the war." ${ }^{2}$ The head of Intelligence, Brigadier Hitchens, responded with a call for a return to first principles, an acceptance that it was not "necessarily Austrian policy at all to rid Austria of the Nazis" but it was the Allied task to enforce denazification, even at the cost of efficiency losses. His optimistic assertion that British policy "is certainly not muddled" was belied by this and subsequent discussions. ${ }^{93}$ Beyond the evident frustration and confusion one thing was clear: there would be no widening and deepening of denazification. On the contrary, British manpower, including intelligence, had already been reduced by the chiefs of staff, and further reductions were on the way. Growing East-West tensions provided a further argument for winding down a policy that seemed to be undermining the Austrian government. These concerns now received the backing of the Foreign Office, which saw Soviet criticism of Austrian denazification as part of a campaign to undermine a pro-Western government. Denazification was "emphatically not a rock on which we want the Austrian ship of state to risk ... floundering [sic]." ${ }^{94}$ Even without the cold war, political opinion in Britain, insofar as it was interested in Austria at all, tended to rally behind the new coalition government; the fears of anti-Prussian conservatives like Lord Vansittart and the solidarity of Labour MPs with the SPÖ converged on this point. Concerns about denazification increasingly focused on its apparent unfairness and its feared disintegrative effects. ${ }^{95}$ The Second Control Agreement of June 1946 provided a formal framework for the British to withdraw from the denazification program. It allowed them to clothe in the mantle of "high policy" what was really a disorderly retreat from a problem that, only a year after the end of the war, appeared intractable. ${ }^{96}$

\section{Federal DenaZification between Allies and Provinces}

Denazification had been instigated by the occupiers and modified through the participation of the province. The federal government was conspicuous by its

${ }_{92}$ Block memorandum, February 27, 1946, PRO, FO1020/1096. See also Stieber, Die Briten, 181 (who wrongly attributes the memorandum to A. C. Wilkinson).

${ }^{93}$ Hitchins, March 12, 1946 (app. A), PRO, FO1020/1097. Stieber, Die Briten, 18081 , wrongly sees this as a representative British view. See the minutes of the BSDC, 8th meeting, March 27, 1946, PRO, FO1007/413.

${ }^{94}$ Cullis, March 22, 1946, PRO FO 371/55256/C3203; Knight, "Entnazifizierungspolitik," 293.

${ }^{95}$ Hansard, House of Lords Debates, vol. 139, cols. 890-98, 907-9; Santo Jeger and Maurice Orbach, Austria 1946 (London, 1946); House of Commons Estimates Committee, Minutes of Evidence Taken before Sub-committee F (London, 1946), paras. 7071; Knight, "Entnazifizierungspolitik," 287.

${ }^{96}$ Philip Nicholls minute, October 19, 1946, PRO, FO945/786; Beer, "Die britische Entnazifizierung," 408-13. 
absence. This was basically because the British refused to recognize the provisional government formed under the auspices of the Red Army in April 1945. The British stance has generally been seen, probably correctly, as shortsighted and counterproductive. Certainly their fear that the head of the government, the veteran Social Democrat Karl Renner, was a pliable figure who had been appointed to pave the way for a Soviet takeover proved wide of the mark. But did the separation of the province from the capital also stymie any chance of effective denazification, as has often been argued? The evidence suggests that it did not. The record of the provisional government is of ministers staggering from one improvisation to the next, arriving by the end of 1945 at a point of almost impenetrable confusion. ${ }^{97}$ Their failure can be explained, first, by the absence of any agreement about what the much-cited distinction between "serious" and "less serious" Nazis should actually mean in policy terms and, second, and more fundamentally, by the extent to which Nazi Party members and their families and friends were embedded in Austrian society.

The Renner government was made up proportionately of representatives of the three "antifascist" parties, but there was no common "antifascist understanding" on how to approach denazification. The cooperation that gradually emerged between the "black" (former Christian Social) and "red" (former Social Democrat) camps was based on avoiding the issue, not on a shared experience of Nazi concentration camps. As in the provinces, neither side had really agreed to bury the hatchets of pre-Anschluss conflict-merely to continue with them sheathed but ready. ${ }^{98}$

If there was common ground in the federal government on the "Nazi question" it lay between the leadership of the Communist Party (KPÖ) and part of the leadership of the People's Party (ÖVP). The latter included the future chancellor Leopold Figl and the party's general secretary (and later education minister) Felix Hurdes. Despite their other fundamental differences in ideology both groups shared an emphatic Austrian nationalist - or patriotic - sensibility, and many had also suffered persecution during the Nazi rule. ${ }^{99}$ Their alignment over denazification can be seen in several cabinet discussions of summer

${ }^{97}$ This can now be followed up to February 11, 1947, in the published cabinet minutes of the Renner and Figl governments; Die Protokolle des Kabinettrates der Provisorischen Regierung Karl Renner, ed. Gertrude Enderle-Burcel, Rudolf Jeřábek, vol. 1 (Vienna, 1995), vol. 2 (Vienna, 2003), vol. 3 (Vienna, 2004); Die Protokolle des Ministerrates der Zweiten Republik: Kabinett Leopold Figl I, vol. 1 (Vienna, 2004), vol. 2 (Vienna, 2005), vol. 3 (Vienna, 2005), vol. 4 (Vienna, 2006).

${ }^{98}$ Elizabeth Klamper, “'Ein einig Volk von Brüdern': Vergessen und Erinnern im Zeichen des Burgfriedens," Zeitgeschichte 24 (1997): 170-82.

${ }^{99}$ This can be seen in the ambivalent admiration shown by the middle-class conservative Josef Schöner for Ernst Fischer in Josef Schöner, Wiener Tagebuch, 1944/1945, ed. Eva-Marie Csáky, Franz Matscher, and Gerald Stourzh (Vienna, 1992), 216, 236. 
1945. Together with the justice minister, Josef Gerö (a lawyer with no party affiliation), they pressed for speedier and more vigorous denazification and expressed growing frustration when this failed to happen. 100

The Socialist leaders in the provisional government - above all Karl Renner (chancellor and, from December 1945, Austria's president), Adolf Schärf (party secretary and then vice-chancellor), and Oskar Helmer (state secretary, then interior minister) - took the party in a new pragmatic direction that contrasted with the traditional rhetoric of Austro-Marxism. ${ }^{101}$ For them the pan-German revolution had been killed by the Anschluss, even though many (including Renner) may still have mourned its passing and still found the notion of an Austrian nation suspiciously reactionary. ${ }^{102}$ The new leadership was also pragmatic on "the Nazi question." 103 Broadly speaking, they took the view that the party could not afford to alienate working-class people and intellectuals who had been recruited into the Nazi Party or the Hitler Youth; they tended to see their motives as economic or instrumental and in that sense excusable. ${ }^{104}$ Renner warned his fellow Socialists on more than one occasion against rejecting these "very valuable" elements, especially since the People's Party enjoyed an established pool of activists from the Cartellverband. ${ }^{105}$

For both leadership and rank and file the dissolution of the party and trade unions by Dollfuss in 1934 was still the prime grievance. The Anschluss was often not seen in the same traumatic light, representing, in the words of Renner, no more than a change from "Mussolini-fascism" to "Hitler-fascism." ${ }^{106}$ Renner and his ministerial colleagues also often appear to have had little appreciation of the murderous dimensions of Nazi racial policy. In some cases (notably that of Oskar Helmer) they held antisemitic views. At any rate they were reluctant

${ }^{100}$ Robert Knight, ed., "Ich bin dafür, die Sache in die Länge zu ziehen”: Die Wortprotokolle der österreichischen Bundesregierung von 1945 bis 1952 über die Entschädigung der Juden, 2nd ed. (Vienna, 2000), 73, 85; Bailer-Galanda, Entstehung, 20-34.

${ }^{101}$ Kurt Shell, The Transformation of Austrian Socialism (New York, 1962).

${ }^{102}$ See Peter Thaler, The Ambivalence of Identity: The Austrian Experience of NationBuilding in a Modern Society, Central European Studies (West Lafayette, IN, 2001), 114-16; also Robert Knight, "Education and Identity in Austria after the Second World War," in The Habsburg Legacy: National Identity in Historical Perspective, ed. Ritchie Robertson and Edward Timms, Austrian Studies, vol. 5 (Edinburgh, 1994), 178-95.

${ }^{103}$ Karl Stadler, Adolf Schärf, Mensch-Politiker-Staatsmann (Vienna, 1982), is generally uncritical; Wilhelm Svoboda, Die Partei, die Republik und der Mann mit den vielen Gesichtern: Oskar Helmer und Österreich II; eine Korrektur (Vienna, 1993) is iconoclastic.

${ }^{104}$ Tim Kirk, Nazism and the Working Class in Austria: Industrial Unrest and Political Dissent in the National Community (Cambridge, 1996); Bukey, Hitler's Austria, 71-92.

${ }^{105}$ Neugebauer and Schwarz, BSA, 44-45; Bailer-Galanda, Entstehung, 120-24.

${ }^{106}$ Renner Protokolle, 1:57. 
to allow Jewish comrades, and potential rivals, to return from exile. It is striking how swift they were to express indignation about the allegedly arbitrary and unjust treatment meted out to former Nazis, comparing it (unfavorably) to Nazi policy even at a point when very few judgments had yet been handed down. ${ }^{107}$

Separating "serious" from "nominal" Nazis has often been seen, wrongly, as some kind of key that policy makers failed, through stupidity or blindness, to use to unlock the door to effective denazification. In fact that separation was the declared aim of all three parties. The Communist leader Ernst Fischer, for example, made no secret of the Communist desire to target those he considered misled or confused ordinary party members. ${ }^{108}$ But he also stressed the need to punish the "hangmen, murderers, and bandits" who had committed crimes. ${ }^{109}$ This points to an important distinction. For Communist and (some) People's Party leaders the notional separation between sheep and goats was to be a preliminary step toward punishing the latter, while for SPÖ ministers it was the reintegration of the sheep that appeared to be the paramount goal.

On paper, the first denazification laws of the provisional government were punitive measures aimed at dealing with the complexity of the Nazi state and party organization. The Prohibition Law (Verbotsgesetz) sought to separate out more serious Nazis on the basis of activity in the illegal pre-Anschluss Nazi Party, which was described as high treason, as well as on the basis of membership in the Schutzstaffel (SS) and paramilitary formations. ${ }^{110}$ As a first step all members of the party (including "candidate members" or Anwärter) and its ancillary organizations were to be registered. More serious Nazis were then to be subject to a range of penalties including imprisonment, dismissal with loss of pension rights, loss of property, and fines. Criminal activity was to be tried under the terms of the War Crimes Law (Kriegsverbrechergesetz), which set up a system of People's Courts. ${ }^{111}$

${ }^{107}$ See, e.g., Helmer in Kabinettsratsprotokoll (KRP) 14th session, June 26, 1945, Renner Protokolle, 1:309; Svoboda, Helmer, 49-51ff.; or (on Renner) Maria Mesner, "Die Unwägbarkeiten der Nachkriegszeit und die Sicherheiten des Kalten Krieges: Die SPÖ-interne Diskussion der Entnazifizierung," in Mesner, Entnazifizierung, 59-76, 65 Margit Reiter, Unter Antisemitismusverdacht: Die Österreichische Linke und Israel nach der Shoah (Innsbruck, 2000).

${ }^{108}$ Ernst Fischer's reported comments to the U.S. diplomat Martin Herz, cited in Understanding Austria: The Political Reports and Analyses of Martin F. Herz, Political Officer of the U.S. Legation in Vienna, 1945-1948, ed. Reinhold Wagnleitner (Salzburg, 1984), 22-23; see Bailer-Galanda, Entstehung, 45.

${ }^{109}$ Fischer in KRP 12th session, June 12, 1945, Renner Protokolle, 1:207.

${ }^{110}$ KRP 12th session, June 12, 1945, Renner Protokolle, 1:205-8; KRP 28th session, August 29, 1945, Renner Protokolle, 2:387-92; also Günter Bischof, Austria in the First Cold War, 1945-1955: Leverage of the Weak (New York, 1999), 57-63.

${ }^{111}$ Kriegsverbrechergesetz/War Criminal Law (Staatsgesetzblatt [StGB1.] 32) June 
However, the denazification law was undermined from the start by the decision to allow appeals and exemptions not merely from punishment but even from the preliminary registration. ${ }^{12}$ Clemency (Nachsicht) could be granted if an individual could show that he or she "had never misused his or her membership in the NSDAP or one of its paramilitary organizations (SA, NSKK, NSFK) and if a positive attitude toward the Austrian Republic can be deduced with certainty from his or her behavior before the liberation of Austria." ${ }^{113}$ As the diplomat Josef Schöner put it in his diary, the law would satisfy the vox populi while Article 27 would deal with "the necessary Rennerish exceptions and pardons." ${ }^{114}$ But the coup de grâce for the law came when this loophole was made available to everyone liable to registration. That decision, whose significance has generally been overlooked, resulted in a flood of applications that placed the skeletal administration in Vienna under an unbearable strain. ${ }^{115}$ Soon afterward Adolf Schärf stated that the mistake had made the law "unwieldy" to enforce. ${ }^{116}$ On June 19, Renner reported that applications for exemptions were "mounting up." 117 By the end of the summer, laws, decrees, and amendments had proliferated, but the confusion had not lessened. ${ }^{118}$ By October, eighty-five thousand out of ninety thousand Nazis liable for

26, 1945; see Claudia Kuretsedis-Haider, "Volksgerichtsbarkeit und Entnazifizierung in Österreich," in Schuster and Weber, Entnazifizierung, 563-601, esp. 586-95. The third "Renner Law" was the Purging of the Economy Law/Wirtschaftsäuberungsgesetz (StGB1. 160), September 12, 1945.

${ }^{112}$ NS Registrierungsverordnung (StGB1. 18), June 11, 1945, secs. 16-32; 3rd Durchführungssverordnung zum Verbotsgesetz (StGB1. 131), August 22, 1945, secs. 14-23; Stiefel, Entnazifizierung, chap. 3.

113 “Ausnahmen von der Behandlung nach den Bestimmungen der Artikel II, III und IV sind im Einzelfalle zulässig, wenn der Betreffende seine Zugehörigkeit zur NSDAP oder einem ihrer Wehrverbände (SS, SA, NSKK, NSFK) niemals mißbraucht hat und aus seinem Verhalten noch vor der Befreiung Österreichs auf eine positive Einstellung zur unabhängigen Republik Österreich mit Sicherheit geschlossen werden kann"; Prohibition Law/Verbotsgesetz (StGB1. 13), May 8, 1945; NS Registrierungsverordnung (StGB1. 18) June 11, 1945, sec. 9.

${ }^{114}$ See Bailer-Galanda, Entstehung, 45; Schöner, Wiener Tagebuch, 239 (entry for May 9, 1945): "Der Volkesstimme ist damit Genüge getan und für die notwendigen Rennerschen Ausnahmen und Pardonierungen sorgt der \$27 des Gesetzes über Ausnahmebestimmungen."

${ }^{115}$ On the significance being overlooked, Stiefel, Entnazifizierung, 88, cites only the amended version (2. Verbotsgesetznovelle) of January 1946 and thus misses the reason for the law's failure.

${ }^{116}$ KRP 11th session, June 4, 1945, Renner Protokolle, 1:182; KRP 14th session, June 26, 1945, Renner Protokolle, 1:310. Schärf's misleading account in Österreichs Erneuerung, 1945-1955: Das erste Jahrzehnt der zweiten Republik (Vienna, 1955), 145-46, blames the People's Party and Communists.

${ }^{117}$ KRP 13th session, June 19-20, 1945, Renner Protokolle, 1:241.

${ }^{118}$ KRP 13th session, June 19-20, 1945, and KRP 14th session, June 26, 1945 , Renner Protokolle, 1:241, 245, 308-13, 315-17; Purging of the Economy Law/Wirt- 
registration (in Vienna and eastern Austria) had applied for exemption. So long as their appeals were pending no further provisions could be enacted. ${ }^{119}$ In addition to lobbying within the nascent state there was intense informal lobbying, notably within the new political parties. ${ }^{120}$ In short, the first federal attempt at denazification was stopped in its tracks after only a few months not, as was later claimed, because it had abandoned the juridical principle of individual treatment but because it had applied that principle too widely.

Meanwhile the political context was changing. In September 1945 the Four Power Allied Commission for Austria was set up, bringing substantial Western military bureaucracies to Vienna; at the end of October the commission gave the Renner government (qualified) recognition; a month earlier the first of three provincial conferences had met in Vienna and, after some reduction in the Communist role and inclusion of more Western provincial representation, it had recognized the provisional government; on November 26 general elections were held in which the Communist party was decimated (gaining only 5.4 percent of the national vote).

These changes brought two opposing pressures to bear on federal denazification. Broadly speaking, the Allies pushed for more action while the party organizations, especially in the provinces, called for less. Allied pressure for "an active, sustained and determined struggle" against the remnants of Nazism and its supporters arose from the short-lived coincidence of Soviet dissatisfaction with the new Austrian government, on the one hand, and U.S. ambitions to extend the scope of denazification, on the other. ${ }^{121}$ The earlier Soviet laissez-faire approach to the Renner state government had not amounted to an endorsement of the denazification, but neither had there been any consistent Soviet pressure on the government to change it. After the Communist election defeat this changed, and a series of frontal attacks on the state of denazification followed. ${ }^{122}$ At the same time the U.S. officials and military who now arrived

schaftssäuberungsgesetz (StGB1. 160), September 12, 1945; 1., 2. NS Registrierungsverordnung (StGB1. 40), June 30, 1945; 3. Durchführungsverordnung zum Verbotsgesetz (StGBl. 131), August 22, 1945.

${ }^{119}$ KRP 37th session, November 6, 1945 (Gerö), Renner Protokolle, 3:221. War crimes trials did however begin in August.

${ }^{120}$ On the SPÖ see Berg, "Die SPÖ"; Wolfgang Müller, "Die Organisation der SPÖ, 1945-1995," in Die Organisation der österreichischen Sozialdemokratie 1889-1995, ed. Wolfgang Maderthaner and Wolfgang Müller (Vienna, 1996), 195-356, esp. 26162 , neglects these informal routes of reintegration.

${ }^{121}$ Allied Council Proclamation to the Austrian People, September 11, 1945, reprinted in Grayson, Austria's International Position, 226-28.

${ }^{122}$ Walter Schuster and Wolfgang Weber, "Entnazifizierung im regionalen Vergleich: Der Versuch einer Bilanz," in their Entnazifizierung, 15-41, 25. See report of meeting of political cabinet with the Soviet general Aleksej Zheltov, KRP 22nd session, July 31, 1945, Renner Protokolle, 2:170-71. 
on the scene were not merely still committed to the Fragebogen system but also, as in Germany, keen to extend it. ${ }^{123}$ At the end of the year Allied bodies began to express dissatisfaction with the number of former Nazi Party members still working as senior civil servants, and a quadripartite Denazification Office began to press the government to dismiss them. The central ministries were scrutinized and instructed to dismiss officials deemed unacceptable; ministers - up to and including the chancellor-were summoned to account by the Allied Council. This pressure gained a foreign policy dimension when the Soviet government cited the inadequacy of Austrian denazification to block discussions on an Austrian treaty in April 1946. ${ }^{124}$

Pressure in the other direction increased as both government and parties extended their authority from eastern Austria to the rest of the country. Within the ÖVP, federal structures brought provincial pressure to restrict purges and an early setback for pronounced anti-Nazi ministers like Figl, Hurdes, and Alois Weinberger. It soon became clear that the latters' attitudes were tougher than those they wished to attract as members or voters. ${ }^{125}$

The SPÖ position was almost a mirror image of this. The Viennese party, which had always been important but was even more so in the limited area of the provisional government, was in general further to the left than the pragmatic leadership of Renner and Helmer, favoring a continued class struggle and rejecting a coalition with the People's Party in terms that differed little from those of the Communists. ${ }^{126}$ This left-wing stance broadly mapped onto a tougher line concerning the "Nazi question," including the rejection of the recruitment of former Nazis. Viennese Socialists like Paul Speiser (deputy mayor of Vienna) and Bruno Marek (later mayor) also strongly disagreed with

${ }^{123}$ See Kurt Tweraser, "Die Amerikanische Säuberungspolitik in Österreich," in Schuster and Weber, Entnazifizierung, 367-68.

${ }^{124}$ See Svoboda, Helmer, 52; Robert Knight, "Kalter Krieg, Entnazifizierung und Österreich," in Meissl, Mulley, and Rathkolb, Verdrängte Schuld, 37-51. Wolfgang Mueller, Die sowjetische Besatzung in Österreich, 1945-1955, und ihre politische Mission (Vienna, 2005), 157, reduces Soviet criticism to this tactical usage. The files of the Quadripartite Allied Denazification Bureau can be found in, among other places, PRO, FO1020/2210 and 2211.

${ }^{125}$ See KRP 33rd session, October 3, 1945, Renner Protokolle, 3:84-86 (Raab); Stiefel, Entnazifizierung, 66-69; Robert Kriechbaumer, "Die Geschichte der ÖVP," in Kriechbaumer and Schausberger, Die Volkspartei, 26; Manoschek, "Erbschaft," $101-2$.

${ }^{126}$ Fritz Weber, Der Kalte Krieg in der SPÖ: Koalitionswächter, Pragmatiker und Revolutionäre Sozialisten, 1945-1950 (Vienna, 1986), 33 (with no reference to denazification); Neugebauer and Schwarz, BSA, 43-45, 65-66; Bailer-Galanda, Entstehung, 43-44; Hans Hautmann and Rudolf Kropf, Die österreichische Arbeiterbewegung vom Vormärz bis 1945: Sozialökonomische Ursprünge ihrer Ideologie und Politik (Linz, 1974), 176-90; Robert Schwarz, "Nazi Wooing of Austrian Social Democracy between Anschluss and War," in Conquering the Past: Austrian Nazism Yesterday and Today, ed. Fred Parkinson (Detroit, 1989), 125-36. 
the proposal to give "less serious" Nazis the vote, Marek calling the proposal a "slap in the face for concentration camp victims and prisoners." By contrast, Socialists outside Vienna tended to support the demand by the "pragmatists" for a softening of the conditions of recruitment into the party. After a series of clashes in August and September within the party Vorstand (the executive committee), the Viennese line initially won out. ${ }^{127}$

In the end it was Allied objections (as well as administrative difficulties) that were decisive in excluding former Nazi Party members from the franchise in Austria's first elections. Even though the extent to which the exclusion was actually enforced remains unclear, SPÖ provincial organizations clearly felt that they had lost votes because of the party's tough line. ${ }^{128}$ As one delegate to the party's first national conference in December put it: "Where we spoke about the Nazi problem we were met by an icy chill, but when we stressed the positive side of the party the masses joined us enthusiastically." Though others pointed to the dangers to the party of admitting, for example, members of the Hitler Youth without intensive party education, the Viennese line was beginning to soften. ${ }^{129}$

Revisions to the denazification law to accommodate these provincial views were now also under discussion. One proposal of the provincial conference aimed at getting out of the morass of deregistration by excluding relatively harmless ancillary groups (for example, NSFK) en bloc. The revised law also corrected the earlier flaw in Article 27; the right of appeal (to be decided by the newly elected President Renner) was now to be limited to "more incriminated" Nazis. But, as Weinberger noted in a cabinet meeting, the real problem was that Nazis with connections - whatever their culpability - could deploy networks of supporters and economic resources in applying for exemptions. ${ }^{130}$ The revised law would not change that. As Minister of Justice Gerö complained, it still allowed both exemptions (by tripartite special commissions) and appeals to the provincial governor (Landeshauptmann). It was hard to see how this would stop the development of what Gerö called "a whole complaints industry [eine ganze Industrie von Beschwerden]" or stop former Nazis implementing their slogan: "misuse democratic instruments to the point where they become a laughingstock."131

${ }^{127}$ Mesner, "Die Unwägbarkeiten," in her Entnazifierung, 64-65; for the mayor of Linz, Ernst Koref, Neugebauer and Schwarz, BSA, 45-47; Renner Protokolle, 3: $106-7$.

${ }^{128}$ On the lack of clarity, see Galanda, Entstehung, 46.

${ }^{129}$ SPÖ, Parteitag 1945: 14. und 15. Dezember 1945 (Vienna, 1946), 92; Neugebauer and Schwarz, BSA, 48-49; Mesner, "Die Unwägbarkeiten," 58-76, 71-72; Doris Sottopietra and Maria Wirth, "Die Länderebene der SPÖ," in Mesner, Entnazifizierung, 77-145, 95-96.

${ }^{130}$ KRP 33rd session, October 3, 1945, Renner Protokolle, 3:99-103 (Altmann).

${ }^{131}$ KRP 37th session, November 6, 1945, Renner Protokolle, 3:220-23; KRP 38th 
Further revisions were discussed within the newly elected government. Helmer argued for the Nazi question "finally to be removed from the agenda" since the mass of former Nazis no longer posed a threat. Once it was gone, he thought the government should make an official declaration of reconciliation. For Helmer, as for much of the media, "the Nazi question" now meant the question of how best to wind up denazification. Those who still saw denazification as a way of punishing or excluding Nazi wrongdoers were finding it increasingly difficult to say how this should be done. It is an indication of this growing bewilderment that Hurdes now came close to throwing overboard the whole basis on which denazification had hitherto been discussed, suggesting that the registration that was about to be started in the western provinces should not be comprehensive but limited from the start to the more serious cases; otherwise, "there too a mountain of files will pile up, which no one knows how to deal with." ${ }^{132}$ The idea was not pursued. Instead, the three parties started negotiations and at the end of March reached agreement. Together with a revised tariff of penalties, the new proposal recommended a basic division between "incriminated" and "less incriminated" Nazis, with less stress placed on membership in the Nazi Party when it had been illegal as a criterion for the former. ${ }^{133}$ Presenting the proposal to the cabinet, Hurdes reviewed the reasons for the failure of denazification since the end of the Third Reich. The fundamental mistake, he thought, had been to allow individual deregistration for everyone. This had been misused by the vast majority of those affected and in combination with patronage and string pulling had paralyzed the law. It was now to be blocked by restricting deregistration to a very few specified groups. ${ }^{134}$ However, since the new law still contained provisions to apply for exemptions and appeals, it was unclear what would now cause the practices Hurdes criticized to cease. The views expressed in the parliamentary debate on the law suggested, to the contrary, that the political atmosphere was becoming more favorable for them. Spokesmen of both main parties expressedwith different emphases - sympathy for the "small" party members. From the media and from Catholic bishops alike came appeals for clemency for those in Allied internment camps. ${ }^{135}$

session, November 16, 1946, Renner Protokolle, 3:257-58; Stiefel, Entnazifizierung, 94.

${ }^{132}$ MRP, 5th session, January 29, 1946, and MRP 7th session, February 5, 1946, Ministerrat Figl I, 1:111, 161.

${ }^{133}$ MRP 23rd session, June 4, 1946, Ministerrat Figl I, 2:186-87.

${ }^{134}$ MRP 25th session, June 12, 1946, Ministerrat Figl I, 2:249-50; Beilage (Erläuternde Bemerkungen zum Nationalsozialistengesetz), ÖStA, AdR; Stiefel, Entnazifizierung, 101-2, 104; Garscha and Kuretsedis-Haider, "Nachkriegsjustiz," 858-59.

${ }^{135}$ Bailer-Galanda, Entstehung, 116; Stieber, Die Briten, 179; Binder, "Rettung," 405. 
While adapting its policies to these pressures from outside Vienna, the government also moved to placate the Allies. Chancellor Figl set up-without parliamentary discussion or legislative backing — a Ministerial Denazification Committee ("Figl Committee") to implement a swift nonbureaucratic purge of the higher echelons of the federal and provincial civil service (encompassing Dienstgrad I-III, i.e., from Regierungsrat upward). Figl told his ministers that the committee's target was "not the small people but the big shots." Those who had been intellectual leaders were "to be removed from public service and the complete administration of the state and the province." He stressed that it was "essential to create the right sort of atmosphere toward the Allied Council, which is required for us to attain a real restoration of a free and independent Austria."136 Figl also dismissed the argument (put forward by the minister of trade and reconstruction) that purges were threatening some who were indispensable: "We've already seen how thousands of Nazis were thrown out overnight and things still carried on. Today everyone claims they were innocent." 137 Figl's initiative was welcomed by the Allies, but their pressure did not immediately lessen. At the start of March, Figl described the whole "Nazi question" as "impossible to unravel" (unentwirrbar). ${ }^{138}$

The knot was not unraveled, but, as Allied pressure lessened, its political impact was neutralized. As we have already seen, the British had in any case always been ambivalent about a widespread purge. The hostility of the British Legal Division toward such a policy even led them to consider intervening to soften the impact of the Austrian legislation on "nominal" Nazis, and they wondered if the policy might have been framed "in order to placate the Allies [sic]." ${ }^{139}$ Perhaps not surprisingly, the minister of justice concluded that the demands of the Allied Council to dismiss more judges and prosecutors, which developed into a major bone of contention in the spring, were mere "shadow boxing" (Spiegelfechterei). ${ }^{140}$ By the end of the year the British authorities had redefined their role in quadripartite committees as being to "ensure that no unnecessary denazification is carried out." ${ }^{141}$ Most important, U.S. policy also shifted away from radical denazification. In the second half of 1946

${ }^{136}$ MRP 4th session, January 22, 1946, Ministerrat Figl I, 1:71-72. See also Wilfried Kos, "Entnazifizerung der Bürokratie," in Meissl, Mulley, and Rathkolb, Verdrängte Schuld, 65-67; Stiefel, Entnazifizierung, 132-35.

${ }^{137}$ MRP 6th session, January 30, 1946, Ministerrat Figl I, 1:144; see also MRP 7th session, February 5, 1946, Ministerrat Figl I, 1:177-78.

${ }^{138}$ MRP 12th session, March 12, 1946, Ministerrat Figl I, 1:321.

${ }^{139}$ Note to Deputy Commissioner on Denazification Policy, n.d., PRO, FO1020/353/ 43A.

${ }^{140}$ MRP 4th session, January 14, 1946, Ministerrat Figl I, 1:74.

${ }^{141}$ Vienna (ACABE) to Control Office ("Denazification: Future British Policy"), March 1, 1947, PRO, FO945/787. 


\section{Knight}

the Moscow Declaration was "reframed," so that its punitive side, which had fed into denazification, was displaced by its commitment to restore independence and sovereignty. In October the State Department declared that it considered Austria to be a liberated country. In this new perspective, any criticism of Austrian denazification appeared to be playing into Soviet hands. ${ }^{142}$

At the end of July the chancellor gave the Allied Council a detailed report on the progress of denazification. Despite private skepticism about the validity of his statistics the West praised the government's achievements. ${ }^{143}$ Admittedly, the Austrian denazification law (now in its third incarnation) was considerably sharpened by the Allies in the second half of 1946, but this was not due to any rediscovered unity. The fifty-five amendments, nearly all of them proposed by the Soviet element (and the French), were simply accepted by the United States and the British occupiers in order to allow the issue to be defused. Once the law was passed it could be removed from the international agenda. As for its actual implementation, the law allowed plenty of scope for the application of what one British legal official called "sagacious negligence."144

The Austrian parliament passed the law under protest in February 1947. ${ }^{145}$ Its draconian provisions prompted an outburst of indignation from most quarters of Austrian public life. But the outburst was actually the best indication that the letter of the law was unlikely to be enforced. ${ }^{146}$ The argument against excluding a large body of citizens from civil life was rehearsed again, by church leaders, politicians, and President Renner. ${ }^{147}$ But their case was much more than a functionalist or utilitarian one: it was couched in the language of compassion and forgiveness. A prominent example was the attack on the new law by the head of state, President Karl Renner. He rejected the idea of "ostracism" both on moral and practical grounds. ${ }^{148}$ It is worth noting that it was not Renner's stance that had changed since 1945 but the context. Instead of having to argue against strong objections both within his own party, the SPÖ,

${ }^{142}$ John Erhardt (U.S. minister, Vienna) to Secretary of State, November 27, 1946, Foreign Relations of the United States (Washington, 1969), 5:380; Bischof, Austria in the First Cold War, 78-79; Rathkolb, "US-Entnazifizierung," 315; Tweraser, "Amerikanische Säuberungspolitik," 380-91; Stiefel, Entnazifizierung, 44.

${ }^{143}$ Allied Council/Minutes (ALCO/M) (46) 27th meeting, July 26, 1946, U.S. State Department, Historical Division, Minutes and Papers of the Allied Commission for Austria, microfilm (Washington, 1958-60); MRP, 34th session, July 30, 1946, Ministerrat Figl I, vol. 3, 79-80.

${ }^{144}$ Deputy Commissioner's Conference, January 22, 1947, PRO, FO1007/267.

${ }^{145}$ Stenographische Protokolle des Nationalrates, 44th Parliamentary Sitting, Fifth Legislative Period, February 6, 1947, cols. 1213-16; Stiefel, Entnazifizierung, 10513; Bailer-Galanda, Entstehung, 116-18.

${ }^{146}$ See Stiefel, Entnazifizierung, 113-14.

${ }^{147}$ See MRP 53rd session, January 21, 1947, Ministerrat Figl I, 4:321.

${ }^{148}$ Karl Renner, "Ich kenne keinen Ostracismus,” Wiener Zeitung, January 1, 1947. 
and within his government, his position was now in the mainstream; his critics were either marginalized or on the defensive. Chancellor Figl himself was a prime example. He had indeed shifted and was no longer urging action against Nazi wrongdoers (including those who had imprisoned him after the $A n$ schluss), as he had in summer 1945, but merely making the tactical case that the denazification law should be accepted as a disagreeable necessity that would "prevent the State Treaty foundering on the Nazi question." 149

Once the measure became law, the path to a party-based reintegration was open. It was clear that Renner himself would have no inhibitions about using his rights under Article 27 to grant clemency. The main question was how the wishes of ministers and parties should be coordinated. As Helmer put it: "I imagine that each party ... will have its people where a special interest is involved. If we decide that the parties can present their applications to the Minister of the Interior, they can be checked there, the questionnaires can be returned, and a referral to the president can follow." Helmer proposed fixing a quota for each party, and this was the basis of the reintegration of first the "less incriminated" and later the "incriminated" Nazis that followed. Four years later Helmer recalled that it had been agreed that each party (including the Communists) would put forward its "house Nazis" to be granted clemency by the president under the terms of Article 27. By 1951 the original quotas of a few hundred had grown into "tens of thousands." 150

\section{Denazification Between Carinthia ANd Vienna}

Federal denazification had to accommodate pressures from the provinces. But at least in the Carinthian case provincial governments could also appear anxious to stay in line with Vienna. This was true even in the summer of 1945 when the British had officially barred them from having any contacts with the Renner government. Though there was little sign of hostility to the capital, there is also little evidence for "love at second sight." 151 While federal politicians did not feel they could take the loyalty of the province for granted, Carinthian politicians were probably aware that the way they had taken over from the Nazi regime left them vulnerable. Attacks from the Yugoslav gov-

${ }^{149}$ MRP 53rd session, January 21, 1947, Ministerrat Figl I, 4:321; Bailer-Galanda, Entstehung, 117; Bailer-Galanda and Garscha, "Der osterreichische Staatsvertrag," 634-35.

${ }^{150}$ MRP 58th session, February 25, 1947, 245th Session, April 24, 1951, ÖstA, AdR; Bailer-Galanda, Entstehung, 157-60, 218.

${ }^{151}$ Robert Kriechbaumer, "Liebe auf den zweiten Blick: Die Länder und der Bund 1945: Zu Vorgeschichte und Geschichte der Länderkonferenz, 1945," in Liebe auf den Zweiten Blick: Landes- und Österreichbewußtsein nach 1945, ed. Robert Kriechbaumer, Geschichte der österreichischen Bundesländer seit 1945, vol. 6 (Vienna, 1998), $15-46$. 
ernment, the Slovene Liberation Front (Osvobodilna Fronta) or even Soviet Radio in Vienna might be discounted. ${ }^{152}$ But criticism from within the federal government must have seemed more serious. At the end of May, a three-man delegation arrived from the capital intending to take over power in the province. The attempt was initiated, or at least approved, by two state secretaries in Renner's government, the Communist Franz Honner (who had fought with the Yugoslav partisans) and the Catholic Raoul Bumballa. ${ }^{153}$ Its clear purpose was to remove what Honner called scathingly "a government that had been formed under the patronage of the old regime." 154 Piesch's designated successor as governor was Otto Zhuber, a former official in the Vaterländische Front who had been imprisoned in Dachau before joining Honner's "Austrian battalions" and fighting under Yugoslav partisan command. ${ }^{155}$ Before leaving Vienna on May 22, Zhuber told Josef Schöner that he intended to "create order in the shortest possible time, even if he had to start off by arresting 1-3,000 people. He would not hesitate to treat the Nazis exactly as they had acted in 1938 and to imprison all the incorrigible ones in camps." ${ }^{156}$ However, the "coup" quickly fizzled out, largely because the British authorities backed Piesch. ${ }^{157}$ But even if it had succeeded Zhuber would have been faced by the difficulty of implementing his radical denazification program; as described by Schöner, the problem was how to find enough "suitable people" in a province where "nearly everyone was in the party." 158

It is likely that it was this incident that led the Carinthian government to introduce its own denazification law for the civil service soon after. As with a further proposal in July, it closely followed the wording of the federal legislation. ${ }^{159}$ Among amendments "appropriate for the Carinthian situation" was

${ }^{152}$ See the report of a broadcast from Soviet-controlled Vienna radio, "Danger over Zone Muddle in Austria," Observer, May 13, 1945; Fran Zwitter, To Destroy Nazism or to Reward It? An Aspect of the Question of Slovene Carinthia (Belgrade, 1947), 11 12, 27-30, 64-69.

${ }^{153}$ On Bumballa's shadowy career, from resistance leader to undersecretary for internal affairs (Unterstaatssekretär für Inneres) see Oliver Rathkolb, ed., Gesellschaft und Politik: Vertrauliche Berichte der US-Militäradministration aus Österreich 1945 in englischer Originalfassung (Vienna, 1985), 176; biographical note in Renner Protokolle, 3:493.

${ }^{154}$ KRP 8th session, May 22, 1945, Renner Protokolle, 1:111.

${ }^{155}$ Rumpler, März 1938, 297; see also (wrongly referring to Robert Zhuber) Erwin Scharf, Ich hab's gewagt mit Sinnen: Entscheidungen im Antifaschistischen Widerstand: Erlebnisse in der politischen Konfrontation (Vienna, 1988), 82-83.

${ }^{156}$ Schöner, Wiener Tagebuch, 232.

${ }^{157}$ Jack Nicholls to Hughes (ACA[BE] Rome), May 23, 1945, PRO, FO1020/976; Austria Report no. 9, Psychological Warfare Branch, July 6, 1945, PRO, FO1007/398; Gruber, Jahre, 45; Schöner, Wiener Tagebuch, 244. For an interpretation that in my view underplays this episode see Stieber, Die Briten, 73.

${ }^{158}$ Schöner, Wiener Tagebuch, 244.

159 "Gesetz über die Reinigung der Beamtenschaft und sonstiger Stellen von Nation- 
the possibility of exemption for those who had joined the SS "under the pressure of mental force and blackmail." Exemptions were to be decided in Klagenfurt, however, not in Vienna. ${ }^{160}$

As contacts with the capital improved, criticism continued. When Honner came to Carinthia he complained about the numbers of Nazi gendarmes and police still in office and the "profascist attitude of numerous district commanders." ${ }^{161}$ Criticism came as well from Ferdinand Graf, ÖVP state secretary for the interior, who was also a leading Carinthian landowner and former official of the Vaterländische Front. ${ }^{162} \mathrm{He}$ expressed "surprise" when he came to Carinthia at the start of September to see that well-known Nazis were still at liberty. ${ }^{163}$ This was the first of several attacks by Graf on former illegal Nazis, whom he described as traitors to Austria, and on the failure of the Carinthian authorities (and by implication the British) to deal with them. The party political element in his attacks was shown in attacks on university-educated Nazis (Akademiker) who had promptly changed "from brown to another color." 164 The color he had in mind was clearly red.

By the end of 1945 it was becoming clear that metropolitan criticism of the Carinthian situation came from only one segment of the political spectrum. Renner himself was ready to take at face value the Carinthian assertion that the province had mounted a successful resistance movement. ${ }^{165}$ And after their election victory in the province it presumably became more difficult for the SPÖ leadership to criticize conditions there. Nevertheless, even here there is some evidence of concern. Helmer reported to his ministerial colleagues that "things are emerging that make an intervention absolutely essential." 166 It seems, however, that he was primarily worried about those who refused to be "reconciled" to the new Austria-that is, those who were drawn to neo-Nazi or "Werewolf" conspiracies. ${ }^{167}$ Those who were ready to be integrated by join-

alsozialisten," PKLR 1, 10th session, May 26, 1945, KLA, LAD. Wilhelm Wadl's argument ("Entnazifizierung," 251) that the proposal was an independent Carinthian initiative seems questionable given similarity of the text to the Vienna law (which had been published on May 9) and the coincidence of Zhuber's visit. See also Sottopietra and Wirth, "Die Landerebene," 114-15.

${ }^{160}$ PKLR 1, 10th session, May 26, 1945; KL 13th session, July 20, 1945, KLA, LAD.

${ }^{161}$ JWIS 18, November 22, 1945, PRO, FO371, 46652/C8994.

${ }^{162}$ Graf had been head of the Carinthian Farming Association (Bauernbund) and a leading figure in the Carinthian Vaterländische Front, an inmate of Dachau and Flossenburg concentration camps. See biographical note in Ministerrat Figl I, 1:626.

${ }^{163}$ CIR 7, September 5, 1945, in Stieber, Consolidated Intelligence Reports, 139.

${ }^{164}$ Ferdinand Graf, "Es muß noch viel geschehen," Volkszeitung, January 4, 1946.

${ }^{165}$ See report by Renner's personal envoy Moser, Memorandum, July 16, 1945, ÖStA, AdR, BKA, BMfAA, 1266-pol/45; KRP 19th session, July 24, 1945, Renner Protokolle, 2:86-87.

${ }^{166}$ MRP 5th session, January 29, 1946, Ministerrat Figl I, 1:115.

${ }^{167}$ See "Minister Helmer bei den Vertrauensmännern der SPÖ," Die Neue Zeit, March 
ing the SPÖ were apparently less of a concern. Although the SPÖ Central Committee was reportedly worried about the protection of Nazis in the Carinthian party and "Piesch's name was mentioned in this connection," recruitment continued. ${ }^{168}$ A year after he had called for a root-and-branch purge of the teaching profession, Piesch was complaining that the purge of teachers had gone much too far. ${ }^{169}$ Before long the Carinthian SPÖ would be seeking credit from the electorate for having restricted the scope of denazification.

When the "Figl committee" arrived in the provinces to review senior appointments in the public sector it was not welcome, as Landesamtsdirektor Karl Newole, who had been instrumental in previous personnel decisions, made clear. In public he made the case that any future purges should concentrate on private industry. ${ }^{170}$ Within the provincial government he forecast dire consequences for the provincial administration "if experienced senior officials are removed." 171 His warnings were followed by similar comments from those in charge of other key sectors of the civil service, such as the police (and gendarmerie). ${ }^{172}$ The future of district administrators (Bezirkshauptleute) was particularly controversial and led to a tug-of-war between capital and province. Some were pensioned off, others transferred to less conspicuous positions, but in the end a bargain was struck based on party parity, the seven posts being distributed to the two main parties in a ratio of 3:3 (with the Klagenfurt position going to a nonparty candidate). ${ }^{173}$

The new federal legislation clearly did not usher in a new chapter in denazification, as some, including the head of Carinthian security, anticipated. ${ }^{174}$

19, 1946. One example that caused concern was the case of Franz Knappitsch: see CIR 19, November 29, 1945, in Stieber, Consolidated Intelligence Reports, 276-77; MRP, 5th session, January 29, 1946, Ministerrat Figl I, 1:116, 133. For examples of Carinthian socialist party intercessions, see Berg, SPÖ, 177.

${ }^{168}$ Weekly Survey of Political Developments (WSPD) 37, March 31, 1946, PRO, FO1007/298; Neugebauer and Schwarz, BSA, 79.

${ }^{169}$ Political Report, June 1946, PRO, FO1007/335.

${ }^{170}$ Karl Newole, "Entnazifizierung," Die Neue Zeit, February 1, 1946.

${ }^{171}$ KLR 7th session, February 8, 1946, KLA, LAD; see also Wadl, "Entnazifizierung," 259.

${ }_{172}$ WSIR 32, February 25-March 3, 1946, PRO, FO1007/305; Sicherheitsdirektion, Situation report, February and March 1946, KLA, LAD.

${ }^{173}$ KLR 14th session, April 3, 1946, KLR 38th session, September 4, 1946, and KLR 10th session, February 27, 1946, KLA, LAD; Newole to Sonderkommission beim BKA, March 9, 1946, ÖStA, AdR, BKA, Entnazifizierung, box 22; Political Report, September 1946, PRO, FO1007/335; see also Elste and Hänisch, Kärnten von der ersten zur Zweiten Republik, 46.

${ }^{174}$ Stossier (Security Director of Carinthia) told the British he anticipated two thousand arrests. Political Report, February 1946, PRO, FO1007/335; Report Stossier January 25, 1946, cited by Stieber, Die Briten, 171, 178; Stiefel, Entnazifizierung, $88-93$. 
The procedure for the mass of members followed the established pattern: registration between February and July 1946 of over forty-five thousand Nazi members and applicant members, coupled with applications for exemption (by about 80 percent of them. $)^{175}$ As for the more serious cases, some were now released from British internment and thus in theory came within the reach of the People's Court in Klagenfurt (a Senat of the Graz People's Court). The first case was a high-profile "euthanasia" trial of doctors and nurses at Klagenfurt Hospital. It ended-not without controversy - in guilty verdicts and death sentences for Franz Niedermoser and two of his assistants. ${ }^{176}$ Further prosecutions followed but they faced various difficulties. Some of these were practical - for example, shortage of manpower and prison space. ${ }^{177}$ Others were legal and political: Austrian prosecutors had to observe due process in a way the British military did not. ${ }^{178}$ Nor could the justice minister intervene when he considered the verdicts of the People's Courts to be too mild. ${ }^{179}$ But the justice system was also more open to the political influence of local elites, as was shown in the case of two prominent timber magnates, Adolf Funder and Franz Hasslacher, who successfully evaded prosecution. ${ }^{180}$ In the case of another local bigwig, Robert Rapatz, who was president of the Chamber of Industry (Wirtschaftskammer) and sat on the provincial denazification com-

${ }^{175}$ Political Report, July 1946, PRO, FO1007/335, gives a total of 45,551. Stiefel (Entnazifizierung, 98) cites a figure of 46,753 contained in a report by the Interior Ministry to the Allied Council (Bundesministerium für Inneres, Überblick über registrierte Nationalsozialisten, September 15, 1946). However, by failing to distinguish between full and candidate members (Anwärter) he radically overestimates the effectiveness of registration; Volkszeitung, March 3, 1946. Wadl, "Entnazifizierung," 257, notes 37,398 requests for clemency out of forty-five thousand registered in February 1946.

${ }^{176}$ Niedermoser was found guilty of killing of at least four hundred adults and children in his charge. See Helga Stromberger, Die Ärzte, die Schwestern die SS und der Tod (Klagenfurt, 1988), 55; Ernst Klee, Was sie taten-was sie wurden: Ärzte, Juristen und anderen Beteiligte am Kranken- oder Judenmord (Frankfurt am Main, 1987), 325 26; Elste, Koschat, and Filipič, NS-Österreich, 55-56.

${ }_{177}$ Garscha, "Entnazifizierung," esp. 861-77.

${ }^{178}$ See House of Commons, Estimates Committee, Report of Subcommittee F (London, 1946), para. 358.

${ }^{179}$ MRP 32nd session, July 17, 1946, ÖStA, AdR (Gerö), Ministerrat Figl I, vol. 3, 26-27.

${ }^{180}$ On Funder's timber and chipboard firm, see Stefan Karner, Kärntens Wirtschaft, 1938-1945: Mit einem Vorwort von Albert Speer (Klagenfurt, 1976), 266; Elste and Hänisch, Auf dem Weg, 280, 292; Wadl, "Entnazifizierung," 260-61. Hasslacher had been a leading Austrian banker (president of the Creditanstalt): see Elste, Braune Elite, 156 n. 679; Elste and Hänisch, Auf dem Weg, 304; Ulrike Felber, Peter Melichar, Markus Priller, Berthold Unfried, and Fritz Weber, Ökonomie der Arisierung, part 2, Wirtschaftssektoren, Branchen, Falldarstellungen, Veröffentlichungen der Österreichischen Historikerkommision, vol. 10 (Vienna, 2004), 517-20, 540; "Verhaftung von Nationalsozialisten," Wiener Zeitung, February 9, 1946. 
mittee, even a combination of pressure from the federal Chancellery, the British, and the Carinthian SPÖ could not offset the political support he had from the Carinthian People's Party. Rapatz remained in office, though he did resign from the denazification committee. He later sat in the upper chamber of parliament (the Bundesrat) for the People's Party. ${ }^{181}$

In the second half of 1946 the remaining impetus from the People's Party was dissipated. Graf continued to complain about the continued activities of former Nazis, including illegals, in the municipal administration of Villach. ${ }^{182}$ Yet before long he had shifted to a stance of solidarity with the Heimat in the border struggle, proclaiming that "all of Austria stands by Carinthia." ${ }^{83}$ The historical legacy or mythology of the endangered province clearly caused ministers to feel they had to demonstrate the government's support. Graf and Helmer both stressed that the mistakes made after the end of the First World War had to be avoided so that the Carinthians "can't say that in Vienna the government doesn't care about these matters and then they can't also claim that they have to protect themselves as in 1918-19."'184 Under these circumstances, criticizing Carinthian denazification appeared inappropriate. Soon the Carinthian People's Party began to try to outflank the SPÖ on the "national question." That meant not merely resisting Yugoslav territorial claims but increasingly also attacking Slovene educational rights. ${ }^{185}$ This campaign was orchestrated by the hero of the "defensive struggle" and veteran German national activist Hans Steinacher. He argued that the defense of the Carinthian Heimat had been seriously weakened by denazification, and he called for it to be dismantled. ${ }^{186}$

The forced resignation of Carinthia's governor, Hans Piesch, in March 1947 provides a snapshot of the state of denazification in Carinthia nearly two years after the end of the Third Reich. The level of Piesch's complicity with National Socialism is less important here than the reasons for, and responses to, his case. Piesch resigned because his activities in support of the Third Reich had

\footnotetext{
${ }^{181}$ Rapatz had been an illegal Nazi member and town master builder (Stadtbaumeister) in Klagenfurt. See Political Reports for July, September, and November 1946, PRO, FO1007/335; Political Intelligence Department (PID) Austrian personalities 48, PRO, FO1007/337; "Konstituierung der Kammer," Kärntner Wirtschaft, December 15, 1946.

182 "Massenversammlung von Vertrauenspersonen," Volkszeitung, March 17, 1946; Graf to Figl, April 26, 1946, Bundesministerium für Inneres (BMI), AdR, BKA, Entnazifizierung, box 22. See "Landesparteitag," Volkszeitung, September 22, 1946. See also Neugebauer and Schwarz, BSA, 93-94.

${ }^{183}$ Ferdinand Graf, "Ganz Österreich steht zu Kärnten,” Volkszeitung, May 1, 1947. See Knight, "Ethnicity and Identity."

${ }^{184}$ MRP Figl I, 57th session, February 18, 1947, AdR, ÖStA.

185 See Binder, "Rettung."

${ }^{186}$ Steinacher memorandum ("Kritische politische Wertung der Schulfrage in Südkärnten samt Folgerungen”), May 6, 1949, ÖstA, AdR, BKA AA, pol/49, Staatsvertrag 2c/80.797-83.944.
} 
exposed him to Yugoslav attacks at a politically sensitive time. Without this international imperative to demonstrate that Austria was "clean" he might well have remained in office. This was certainly the view of his party leader, ViceChancellor Schärf, who was nonchalant about what he called Piesch's "mild show of collaboration," seeing it as the only alternative to Dachau, military service or death. ${ }^{187}$ More striking perhaps was the attitude of Chancellor Figl to the SPÖ's embarrassment. Though he called the revelation a "dirty business," he also "hoped that it would not become public knowledge." That it did not must itself be ascribed in large part to the ÖVP's restraint in not allowing the details of the affair to become public. The Carinthian People's Party also showed restraint, its leader stressing within the provincial government that his party had had nothing to do with the "witch hunt" (Kesseltreiben) against Piesch. The People's Party newspaper suggested that the SPÖ had merely reaped what they themselves had sown with their attacks on Rapatz. The invitation to exercise mutual restraint in future was clear enough. ${ }^{188}$ As for the British, Piesch's resignation clearly called into question both the decisions they had made in the first few weeks of occupation and, indeed, their current stance of laissez-faire. The British minister in Vienna, William Mack, who two years before had described Piesch as "universally recognized as a reliable anti-Nazi," was now astonished that "this information [about Piesch's past] had not been available earlier." 189 The Foreign Office was concerned about Schärf's attitude and wondered if its previous assumption that the Austrian authorities would "prevent Nazis from obtaining senior posts in the Government service" was correct. Mack responded that he could not guarantee that "no more Piesches [sic]" would be found but that it was "not possible for the intelligence Organisations at any rate at this stage of the occupation to probe into the records of politicians and officials." 190

\section{CONCLUSION}

This article has examined the assumptions, goals, and strategies of the main actors involved in Carinthian denazification. What conclusions can be drawn about the quality of the democracy that emerged from it? Five are offered here.

${ }^{187}$ Schärf told Mack that he did not blame those who decided on some form of collaboration, and he thought that "Herr Piesch could return to the office that he had vacated after the occupation." Mack to Bevin, March 14, 1947, PRO, FO371/63958/ C4437. For similar exonerations see Berg, "Die SPÖ," 164-66.

${ }^{188}$ KLR 55th session, March 12, 1947, KLA, LAD; "Landeshauptmann Piesch zürückgetreten," Volkszeitung, March 13, 1947.

${ }^{189}$ Mack to Pol. Div., June 6, 1945, PRO, FO371/46649/C3322; Mack to Bevin, March 14, 1947, PRO, FO371/63958/C4437.

${ }^{190}$ Burrows to Mack, April 12, 1947, PRO, FO371/63958/C4437; Mack to Burrows, May 28, 1947, PRO, FO371/63958/C4437; (Peter) Nicholls minute, June 7, 1947, PRO, FO371/64653/C7697. 
First, the self-critical reflection on Nazi criminality that Helmut Dubiel sees as a central democratic goal for a post-Nazi society was as conspicuously absent in Carinthia as in West Germany. The national dimension, Austria's questionable legitimation as "the first victim of Hitlerite Aggression," is of course well known. To see this as an act of united evasion - whether reprehensible or unavoidableis misleading since, as has been shown, sections of Austria's postwar elites did in fact push for the punishment and exclusion of wrongdoers. However, in the course of the first two postwar years they were either politically marginalized or became resigned to what appeared an unavoidable failure. As early as the summer of 1945 it became clear that the intended objects of purges could still deploy enough resources to undermine, delay, and in the end reverse the measures aimed at them. For this reason the distinction between a small number of "big fish" and a mass of "small fry" that ran through the rhetoric of denazification misses the point. There were fish of all sizes, many had plenty of water to swim in, and plenty could hire good lawyers.

Second, this account of denazification and its failure tends to undermine the notion of a "functionally necessary" reintegration. Naturally the claim that most followers of National Socialism would at some point have to be given full citizenship if Austrian (or German) society were to function is hard to contradict as a general proposition. But integration was as much about values as about the rationality of a "system" and cannot be separated from the normative terms under which it took place. In particular, the claim that those returning were rigorously vetted and systematically taught or retaught democratic values is hard to sustain. ${ }^{191}$ Further research is clearly required, but the converse possibility, which was raised by some contemporaries, also needs to be considered: that those readmitted might themselves influence the organizations and the society they joined, whether in the form of the kind of organized "permeation" seen in the West German Free Democratic Party (FDP) or through more informal networks. ${ }^{192}$ Reintegration could then also mean a rehabilitation that was more than an individual one and that extended if not to the whole National Socialist project at least to aspects of it. The central example in the Carinthian context is the steady shift of both parties away from support of Slovene collective rights. Here "taking the wind out of German national sails" might actually increase the momentum of those who believed that Carinthia should become a purely German-speaking society. ${ }^{193}$

\footnotetext{
${ }^{191}$ Here Matt Berg ("Die SPÖ”) seems to me overoptimistic about the rigor of SPÖ vetting.

${ }^{192}$ See the monthly report for the Carinthian Security Direction, December 1954 (Villach), ÖstA, AdR, BMI, 30.000 2/54.

${ }^{193}$ See, among others, Robert Knight, "Schule zwischen Zwang und Verantwortung: Britische Besatzung, Kärntner Politik und die slowenische Minderheit, 1945-1959,"
} 
Third, a selective or "discriminating" reintegration —one that would still involve drawing a line against those guilty of serious misdeeds - would always be difficult, since discrimination depended on the preexisting sensibility about Nazi criminality that was far from firmly established. But what probably made it impossible was the system of regulated competition and bargaining known under the shorthand of Proporz. This helped turned reintegration into a freefor-all in which nearly all sense of restraint disappeared. Some objections were voiced within both parties but they received short shrift from the party leadership. ${ }^{194}$ Here the "overarching elite consensus" and the top-down decision making noted by students of Austria's "consociational democracy" appear as a system of wheeling and dealing. Arguably denazification also explains why that system, for all its effectiveness in many areas, also contributed to pervasive cynicism about Austrian public life. Forty years later it was still a characteristic stance of the FPÖ to castigate the hypocrisy of the two main parties and question the genuineness of their "antifascism" by reference to their readiness to bend the rules of denazification.

Fourth, Carinthia was reintegrated into the Austrian federal state far more successfully than it had been into the First Republic, but the reintegration came not through harmony but through often tense negotiation. For obvious reasons the Anschluss was taboo. Nostalgia for it or identification with a Greater Germany now had to be encoded, though in the case of the veterans' commemoration the code was not hard to crack. ${ }^{195}$ While provincial resentment of the capital clearly no longer had the political impetus that had existed in 1938, it had hardly disappeared. ${ }^{196}$ The mythology of the Carinthian Heimat as a German bulwark was largely shorn of any overt geopolitical message. But it continued to exert a powerful polarizing effect on provincial politics, above all in relation to the Slovene minority. Helped by Yugoslavia's policy of claiming Carinthian territory, it meant that those Slovene speakers who were not prepared to assimilate were considered actual or potential traitors. This is not to deny that there were supporters of minority rights in both the SPÖ and the ÖVP, but they were steadily placed on the defensive. The politics and rhetoric

in Österreich unter alliierter Besatzung, 1945-1955, ed. Alfred Ableitinger, Siegfried Beer, and Eduard Staudinger (Vienna, 1999), 531-58; Svila Tributsch, "Der Konflikt um die zweisprachige Schule in Kärnten von 1945 bis 1959," in Karner and Moritsch, Aussiedlung - Verschleppung — nationaler Kampf, 79-98.

${ }^{194}$ On the SPÖ see Neugebauer and Schwarz, BSA, 94-96, 233-38.

${ }^{195}$ Sieglinde Rosenberger and Reinhold Gärtner, Kriegerdenkmäler (Innsbruck, 1991), 28; Matthew Paul Berg, "Challenging Political Culture in Postwar Austria: Veterans' Associations, Identity, and the Problem of Contemporary History," Central European History 30 (1998): 513-44.

${ }^{196}$ Helmut Rumpler, "Kärnten und Österreich: Eine unbeglichene historische Rechung," in Kriechbaumer, Liebe auf dem Zweiten Blick. 


\section{Knight}

of the Heimat provided the opponents of minority rights with a natural habitat. At the annual October 10 celebrations the mythology of the Carinthian Heimat was ritually reaffirmed. No space was allowed here for critical self-reflection on the persecution of the Slovene minority, much less on the implication of German nationalism in Nazi rule. ${ }^{197}$ After the brief postwar intervention phase described in this article, national politicians generally accepted this Heimat culture, whether out of a sense of weakness or because of electoral calculation. Often they were ready to exploit it themselves. ${ }^{198}$

Fifth, the occupation authorities in Carinthia and elsewhere in Austria were not interested or concerned enough to intervene seriously in its politics. Austria did not receive its liberated status "on a platter," as sometimes maintained, and Allied denazification proceeded on a premise broadly similar to that applied in Germany, but fewer resources were deployed. As the flaws of the policy became clear, the occupiers sought to remedy them by involving Carinthian elites; thus party politics moved to the center of denazification. The growing confusion surrounding British policy was (thinly) veiled by the "high policy" imperatives of handing over responsibility to the Austrian government and defending it against Soviet (and Yugoslav) attacks. So long as the formal conditions of democracy and the taboo on the Anschluss were observed, the occupation authorities saw no reason to change their laissez-faire stance. This contrasts starkly with the monitoring and intervention in the early Federal Republic of both the U.S. and British authorities, whose role in setting normative limits (Grenzmarkierung) has been stressed by Norbert Frei and others. ${ }^{199}$ Apart from occasional journalistic forays, the quality of the democratic culture in Austrian provinces was not an issue for the outside world, and it did not become one for another forty years. ${ }^{200}$

${ }^{197}$ Christian Pichler, "Politische Gedenktage und die deutschsprachige Kärntner Presse (1945-2000)," in Politische Festtagskultur-Einheit ohne Einigkeit? ed. Ulfried Burz and Heinz Dieter Pohl, Kärnten und die Nationale Frage, vol.3 (Klagenfurt, 2005), 204-45.

${ }^{198}$ See Binder, "Rettung," 416-17.

${ }^{199}$ Norbert Frei, Vergangenheitspolitik: Die Anfänge der Bundesrepublik und die Vergangenheit (Munich, 1996), 361-96; similarly, Ulrich Herbert, Best: Biographische Studien über Radikalismus, Weltanschauung und Vernunft, 1903-1989 (Bonn, 1996); Hermann-Josef Rupieper, Die Wurzeln der Westdeutschen Nachkriegsdemokratie: Der Amerikanische Beitrag, 1945-1952 (Opladen, 1993).

${ }^{200}$ See, among others, Andrei Markovits, "Austrian Exceptionalism: Haider, the European Union, the Austrian Past and Present," in Wodak and Pelinka, Haider Phenomenon, 95-119; Pieter Judson, "Austrian Non-reception of a Reluctant Goldhagen," in The "Goldhagen Effect": History, Memory, Nazism-Facing the German Past, ed. Geoff Eley (Michigan, 2000), 131-50. 